\title{
Inefficiencies in the Information Thicket: A Case Study of Derivative Disclosures During the Financial Crisis
}

\author{
Robert P. Bartlett, III*
}

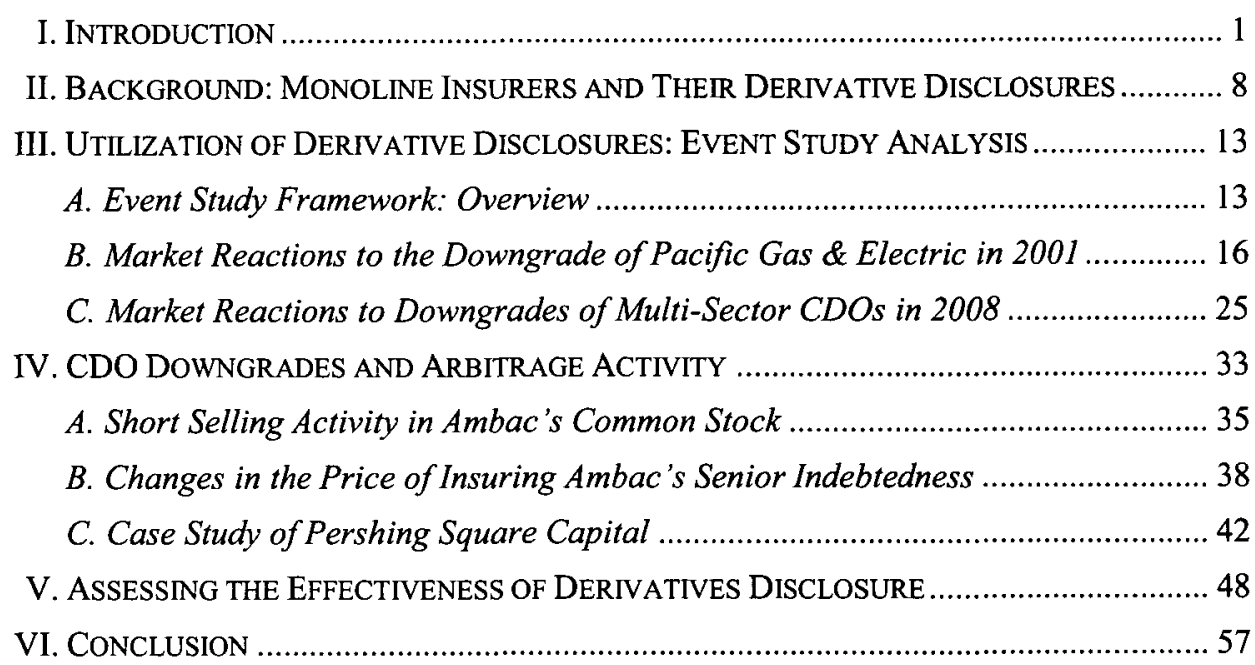

\section{INTRODUCTION}

It is now accepted wisdom that a principal contributing factor to the destabilization of the financial system in 2008 was the notable lack of transparency in what has colloquially been dubbed "the shadow banking system." Starting in the early 1990s, this

\footnotetext{
* Assistant Professor of Law, UC Berkeley School of Law. I thank Dick Buxbaum, Jim Cox, Steven Davidoff, Vic Fleischer, David Gamage, George Geis, Mike Guttentag, Donald Langevoort, Bob Lawless, Su Li, Justin McCrary, Victoria Plaut, Frank Partnoy, Larry Ribstein, Usha Rodrigues, Mike Simkovic, Gordon Smith, Eric Talley, Ken Taymor, Josh Teitelbaum, Robert Thompson, Mike Wells, workshop participants at Georgetown, Illinois, and Vanderbilt, as well as participants at the 2010 Law and Entrepreneurship Retreat and the 2010 annual meeting of the American Law and Economics Association. Additionally, special thanks go to Pershing Square Capital for providing access to their Open Source Financial Model, and to Gary Peete and Karen Wang (Berkeley '10) for research assistance. All errors are my own.

1. See, e.g., Viral V. Acharya et al., Derivatives: The Ultimate Financial Innovation, in RESTORING FINANCIAL STABILITY: How to REPAIR A FAILED SYSTEM 233, 241 (Viral V. Acharya \& Matthew Richardson eds., 2009) (noting that despite the significant growth of the credit default swap and CDO markets by 2008, "there was a complete lack of transparency about the underlying exposures of financial institutions to this market”); Martin N. Baily \& Robert E. Litan, A Brief Guide to Fixing Finance, in FIXING FinanCE 6, 12 (2008), (The Brookings Inst. Ser. No. 1), available at http://www.brookings.edu/papers/2008/0922_fixing_finance baily_litan.aspx ("One key problem with financial innovation in recent years has been that many of the securities and the financial institutions that issued or held them have been less than transparent.").
} 
broad swath of non-bank organizations-including investment banks, insurance companies, and hedge funds-created a significant network of financial intermediaries and investors that was capable of funding and trading any number of loan products that had traditionally been in the domain of commercial banks, including credit card receivables, commercial loans, and most notably, residential home mortgages. Through securitization, an investment bank could form a collateralized debt obligation (CDO) to acquire a portfolio of loans from one or more loan originators, the funds for which would be raised through the CDO's issuance of multiple tranches of notes to institutional investors. However, because both the issuance of notes and their subsequent acquisition were generally exempt from the reporting requirements of U.S. securities laws, it was often unclear where the financial risk of these investments ultimately resided. ${ }^{2}$ When real estate losses began to mount in 2007, this uncertainty regarding firms' derivative exposure to these losses brought inter-firm lending to a halt, eventually producing the de facto bank runs that would destroy both Bear Stearns and Lehman Brothers. ${ }^{3}$

The opacity with which financial institutions accumulated significant exposures to credit derivatives has naturally led to a variety of U.S. and international reform proposals aimed at casting light on this important corner of the financial sector. ${ }^{4}$ Consistent with

2. Even when large, publicly-traded financial services firms acquired significant exposures to CDOs backed by subprime mortgages, the firms' reporting obligations under both U.S. securities laws and U.S. Generally Accepted Accounting Principles (GAAP) typically required only aggregate disclosures of their fixed income investments. See, e.g., FINANCIAL ACCOUNTING STANDARDS BOARD, STATEMENT of FINANCIAL ACCOUNTING STANDARDS No. 115: ACCOUNTING FOR CERTAIN INVESTMENTS IN DEBT AND EQUITY SECURITIES (1993), available at www.fasb.org/pdf/fas115.pdf (requiring all reporting entities to "disclose the aggregate fair value" for securities classified as available-for-sale); see also ERNST \& YOUNG LLP, FINANCIAL REPORTING DEVELOPMENTS: ACCOUNTING FOR CERTAIN INVESTMENTS IN DEBT AND EQUITY SECURITIES (2009) (summarizing disclosure obligations with respect to securities that are available-for-sale and held-tomaturity). The 2006 annual report for Lehman Brothers, for instance, provided but a single paragraph to describe its CDO activities, notwithstanding the fact that losses associated with its CDO portfolio would be a key factor in the firm's collapse. As is well known, disclosures made by AIG regarding its portfolio of credit default swaps written on multi-sector CDOs were similarly sparse until their collateral requirements forced the firm into bankruptcy in September 2008. See Frank Partnoy, Historical Perspectives on the Financial Crisis: Ivar Kreuger, the Credit-Rating Agencies, and Two Theories About the Function, and Dysfunction, of Markets, 26 YALE J. ON REG. 431, 436 (2009) ("The major banks' . . CDO exposures did not appear in their financial statements before 2008.").

3. See Viral V. Acharya \& Matthew Richardson, Mortgage Origination and Securitization in the Financial Crisis, in RESTORING FINANCIAL STABILITY: How TO REPAIR A FAILED SYSTEM 61, 74 (Viral V. Acharya \& Matthew Richardson eds., 2009) (noting that a lack of transparency led to mistrust, a risk aversion, and the freezing of credit markets); THE COMMITTEE OF EUROPEAN SECURITIES REGULATORS, TRANSPARENCY OF CORPORATE BOND, STRUCTUREd FINANCE PRODUCT AND CREDIT DERIVATIVES MARKETS, CONSULTATION PAPER 47 (Dec. 19, 2008), available at http://www.cesr-eu.org/data/document/08_1014.pdf (noting that the "lack of transparency about positions and about the full extent of market-wide exposures led to heightened concerns amongst the market").

4. See, e.g., Committee on Capital Markets Regulation, The Global financial Crisis: A Plan FOR REGULATORY REFORM 151 (2009) (recommending enhanced disclosure by structured finance vehicles "to allow investors to complete their own credit analysis . . .."); SQUAM LAKE WORKING GROUP ON FINANCIAL REgUlation, A NEW INFORMATION INFRASTRUCTURE FOR FiNANCIAL MARKETS (2009) (proposing a new information infrastructure to manage systemic risk in which large financial institutions provide government regulators with the identity of individual derivative positions that would then be released to the public to enable private actors to complement government analysis), available at http://www.cfr.org/publication/18568/new information_infrastructure_for_financial_markets.html; Press Release, Financial Accounting Standards Board, 
conventional securities regulation policy, these proposals generally assume that requiring greater, more granular disclosure of a firm's derivative credit exposures, together with more detailed disclosures of the assets underlying these exposures, should enable investors to conduct the type of independent analysis of a firm's derivative exposure to credit risk that was arguably missing during the credit boom of 2003 to 2007 and the financial turmoil of 2008. Rather than rely on a firm's own assessment of its balance sheet or the credit rating assigned to it by a potentially conflicted credit rating agency (CRA), investors could utilize these disclosures to build their own credit models, thereby bringing greater market discipline on a firm's credit derivative activities while minimizing uncertainty about credit risk during periods of financial stress.

A central challenge facing these proposals, however, is understanding the extent to which market participants will actually use these additional disclosures. Valuing even a single CDO investment-let alone a portfolio of such investments-requires a multifaceted analysis of a considerable amount of both legal and financial data, ranging from an estimation of the default and prepayment risks of hundreds, potentially thousands, of underlying loans, analysis of the particular overcollateralization and subordination provisions attaching to particular tranches of CDO securities, and an assessment of potential counterparty risk of the CDO's various hedge counterparties. For this reason, academic commentary on the effect of enhanced derivative disclosures has frequently been skeptical of the benefits of enhanced disclosure, suggesting instead that the complexity of many credit derivatives-especially those tied to structured finance vehicles such as CDOs-may make it impossible for markets to incorporate additional information in a meaningful way. ${ }^{5}$ To the extent that this is the case, enhancing

FASB Staff Position No. 133-1 and F11445-4, Disclosures about Credit Derivatives and Certain Guarantees: An Amendment of FASB Statement No. 133 and FASB Interpretation No. 45; and Clarification of the Effective Date of FASB Statement No. 161 (Sept. 12, 2008), available at http:/www.fasb.org/jsp/FASB/Page/ nr091208.shtml (requiring enhanced disclosure requirements for sellers of credit derivatives and financial guarantees); Margaret M. Blair \& Erik F. Gerding, Sometimes Too Great a Notional: Measuring the "Systemic Significance" of OTC Credit Derivatives, LOMBARD ST., Aug. 2009, at 10, 11 (proposing that the "Federal Reserve (or other systemic risk regulator) ... require that financial institutions publicly disclose detailed information on the size, counterparties, and closing dates of credit derivatives in their portfolio on a regular and frequent basis, such as at the close of business each business day."). A central feature of the recently enacted Dodd-Frank Wall Street Reform and Consumer Protection Act has similarly been to ensure greater transparency of firms' exposure to derivatives. In particular Title VII of the Act mandates regulated, centralized clearing and trading for certain swap agreements as well as a requirement that all swaps, whether cleared or uncleared, be reported to a "swap data repository" (a registered entity that collects and maintains records with respect to transactions or positions in swaps). Dodd-Frank Wall Street Reform and Consumer Protection Act, Pub. L. No. 111-203, $\S \S 727,763,124$ Stat. 1376, (2010) [hereinafter Dodd-Frank]. Any swap repositories must, in turn, make available to the Commodity Futures Trading Commission, the Securities and Exchange Commission, and certain other regulators "all data obtained by the swap repository, including individual counterparty trade and position data." Id. $\S \S 728,763$. Although Dodd-Frank presently limits the disclosure of such information to regulators, it granted both the newly created Financial Stability Oversight Council (FSOC) as well as the Federal Reserve Board (FRB) broad authority to require additional periodic public disclosures of any "large, interconnected bank holding companies" as well as any nonbank financial companies supervised by the FRB to "support market evaluation of the risk profile, capital adequacy, and risk management capabilities thereof." Id. § 115(f); see also id. $\S 165$ (d) (authorizing the FRB to prescribe "enhanced public disclosures" for such firms).

5. See, e.g., Steven L. Schwarcz, Rethinking the Disclosure Paradigm in a World of Complexity, 2004 U. ILL. L. REV. 1, 19 (arguing that many legitimate transactions in which securities are issued are "so complex that 
derivative disclosures will simply add to the burden of periodic reporting requirements for financial institutions, potentially driving finance to use less efficient forms of organization. From a regulatory design perspective, overestimating the potential for market participants to police credit derivatives may also detract from other, more effective regulatory initiatives. ${ }^{6}$

To understand better whether enhanced derivative disclosures can play a role in systemic risk regulation, this Article turns to a unique corner of the financial sector that is ideally suited to study how greater derivative disclosures might have affected the Financial Crisis of 2008. Alternatively known as the "monoline insurance" or "financial guarantee industry," from 2005 to 2008 , this industry was both deeply exposed to complex credit derivatives tied to residential home mortgages and subject to considerable disclosure obligations regarding its credit derivative activities. ${ }^{7}$ To date, however, regulators and scholars alike have largely overlooked the disclosure experience of the industry notwithstanding its critical role in the Financial Crisis. Although traditionally focused on providing insurance against the default of municipal bonds, monoline insurers expanded during the 1990s to guarantee the principal and interest on bonds issued by structured finance vehicles, and by 2005 they were increasingly selling credit default swaps on bonds offered by multi-sector CDOs backed by prime and sub-prime mortgages. ${ }^{8}$ Indeed, by 2007 the two largest monoline insurers-Ambac Financial Group (Ambac) and MBIA - had each sold credit default swaps on approximately $\$ 30$ billion of bonds issued by multi-sector CDOs making their combined exposure to these instruments approach that of AIG Financial Products. ${ }^{9}$

less than a critical mass of investors can understand them in a reasonable time period [and to that extent] the market will not reach a fully informed price equilibrium, and hence will not be efficient"); COUNTERPARTY Risk Management Policy Group III, Containing Systemic Risk: The Road to Reform 53 (2008), available at http:/www.crmpolicygroup.org/docs/CRMPG-III.pdf (observing that even with complete disclosure in the essential documentation, the traits of structured finance securities were not comprehended by many large integrated financial intermediaries, hedge funds, specialized financial institutions, and others in the market); see also Letter from Warren Buffett, Chairman of the Board, Berkshire Hathaway lnc., to the Shareholders of Berkshire Hathaway 17 (Mar. 2, 2009), available at http://www.berkshirehathaway.com/letters/ 2008ltr.pdf ('Improved 'transparency'-a favorite remedy of politicians, commentators and financial regulators for averting future train wrecks-won't cure the problems that derivatives pose. I know of no reporting mechanism that would come close to describing and measuring the risks in a huge and complex portfolio of derivatives .... When I read the pages of 'disclosure' in $10-\mathrm{Ks}$ of companies that are entangled with these instruments, all I end up knowing is that I don't know what is going on in their portfolios (and then I reach for some aspirin)." (emphasis in original)).

6. Most notably, unrestrained belief in the power of disclosure to police credit derivatives might detract from those reform efforts that focus more on improving the federal government's resolution authority over failing financial institutions. See Steven L. Schwarcz, Systemic Risk, 97 GEO. L.J. 193, 195, 225, 238 (2008) (arguing that effective regulation of systemic risk ultimately requires a "liquidity-provider of last resort" and concluding that "mandating increased disclosure would do relatively little to deter systemic risk and may even be counterproductive").

7. See infra notes $26-42$ and accompanying text (describing historical and current disclosure practices in the monoline insurance industry).

8. See sources cited infra note 29.

9. See Ambac Financial Group Inc., Annual Report (Form 10-K) 59 (Feb. 29, 2008), available at http://www.ambac.com/AR2007/Ambac2007_10K.pdf [hereinafter Ambac 2007 10-K Report] (noting that Ambac had an exposure at December 31, 2007 of $\$ 29.1$ billion to CDOs comprised of at least $25 \%$ mortgagebacked securities); MBIA Inc., Annual Report (Form 10-K) 66 (Feb. 29, 2008), available at http://www.sec.gov/ 
Yet in contrast to AIG's portfolio of credit default swaps - the details of which were not disclosed publicly until January 2010-a combination of the statutory accounting rules that apply to financial guarantee companies and the voluntary disclosures made by Ambac and MBIA during the Financial Crisis resulted in the quarterly disclosure of their largest exposures, including their multi-sector CDO exposures. At the same time, a peculiar coincidence involving European regulatory developments, offering practices within the CDO market, and the particular timing of the insurers' entry into the CDO market had the effect of making available to the public a large amount of legal and financial data on each insured CDO. As a result, for almost every CDO in Ambac and MBIA's portfolio during the run-up to the Financial Crisis in 2008, it was possible to obtain a complete description of the specific indenture provisions pertaining to the tranche of notes guaranteed (such as overcollateralization provisions and default protections), information about portfolio composition, and the identity of critical third parties such as swap counterparties, liquidity providers, and indenture trustees. ${ }^{10}$ Equally important, investors could use this information to obtain from the indenture trustee's website the CDO's monthly remittance reports, which provided detailed financial information concerning each security in the CDO's portfolio, the portfolio's overall performance, and the monthly cash flows to the particular tranche of notes guaranteed. In short, the unique circumstances that applied to Ambac and MBIA in 2008 permitted market participants to engage in precisely the type of fundamental analysis of a firm's credit derivatives that was not possible with firms such as AIG or Lehman Brothers.

For similar reasons, examination of the monoline industry also permits a case study of how investors might use enhanced derivative disclosures to alleviate the uncertainty associated with assessing the risk of a complex derivative such as a CDO. That is, to the extent greater disclosure by a financial firm of its derivatives positions can reduce uncertainty in times of financial stress, evidence of this effect should have appeared in the asset pricing of monoline insurance companies during the Financial Crisis of 2008. Conversely, if derivatives such as CDOs are in fact too complex for market participants to analyze in a reasonable period of time, evidence of this type of informational inefficiency should also have appeared in the behavior of monoline investors. In particular, the failure of monoline investors to respond to an abrupt change in the credit risk of an insured CDO or an announcement by an insured CDO's trustee that it has commenced liquidation might each suggest inefficiencies in investors' ability to process disclosures about the type of complex credit derivatives that were at the epicenter of the Financial Crisis.

To assess which of these two scenarios applied to the monoline industry during the Financial Crisis, this Article uses two principal strategies. First, to examine whether the insurers' derivative disclosures might have produced more efficient asset pricing, I turn

Archives/edgar/data/814585/000119312508042602/d10k.htm [hereinafter MBIA 2007 10-K Report] (noting MBIA had an exposure at December 31, 2007 of $\$ 30.1$ billion to multi-sector CDOs). At the time of its collapse in September 2008, AIG Financial Products had a gross notional exposure to multi-sector CDOs of approximately $\$ 72$ billion. See CONGRESSIONAL OVERSIGHT PANEL, JUNE OVERSIGHT REPORT: THE AIG RESCUE, ITS IMPACT ON MARKETS, AND THE GOVERNMENT'S EXIT STRATEGY 31 (2010), available at http://cop.senate.gov/documents/cop-061010-report.pdf.

10. See infra notes $26-42$ and accompanying text (discussing the disclosure practices within the monoline insurance industry). 
to an event study framework of one of the largest monoline insurers, Ambac Financial. Given the emphasis on the role that complexity might play in impeding effective disclosure, the analysis begins by examining the effect of the firm's derivative disclosures in the context of its traditional bond underwriting business. As shown below, analysis of the bankruptcy of Pacific Gas \& Electric (PG\&E) in 2001-one of the few instances when monoline insurers experienced a significant loss payout in their insured bond portfolio-indicates that investors could be quite sensitive to news affecting the credit risk of ordinary bonds insured by monoline insurers. The initial credit downgrade of PG\&E, for instance, resulted in sudden and significant negative abnormal returns for Ambac as investors appeared to use the new information to reassess the firm's financial position. More importantly, the size of the price adjustment relative to that of MBIAanother insurer of PG\&E's debt-was closely calibrated to the size of Ambac's disclosed exposure to PG\&E, suggesting that with respect to ordinary bond insurance, investors were capable of efficiently processing the monolines' portfolio-level disclosures.

In contrast to the PG\&E experience, however, a similar set of event studies conducted on the downgrades during early 2008 of Ambac's insured multi-sector CDOs reveals no similar market price reaction. In particular, four of the CDOs insured by Ambac experienced multi-notch downgrades in 2008 during periods that were generally free from other confounding events and yet produced no notable stock price reaction for Ambac. ${ }^{11}$ Nor do any notable reactions appear in Ambac's bi-monthly short-selling data or in the daily pricing of credit default swaps (CDS) written on its senior debt securities. ${ }^{12}$ The absence of any significant market reaction is especially notable in light of the fact that both the amount of potential claims and the significance of the credit downgrades were larger in magnitude than in the case of PG\&E.

To be sure, the existence of publicly-available "lower-tier" data about the CDOs in Ambac's structured finance portfolio, such as the individual prospectuses and monthly remittance reports, may have enabled investors to construct their own credit assessment of Ambac's portfolio, thus freeing them from relying on credit rating downgrades. To the extent this occurred on a regular basis, one might therefore expect a muted reaction to the (presumably) well-anticipated downgrade announcements. Moreover, using an event study framework to examine the effect of these information disclosures would be impracticable if investors used this information to engage in more gradual, Bayesian updating of Ambac's equity valuation.

To determine whether investors in Ambac might be conducting these more granular analyses using lower-tier data, I analyzed a prominent portfolio model of Ambac and MBIA conducted in January 2008 by the hedge fund Pershing Square Capital. ${ }^{13}$ Throughout 2007 and 2008, Pershing Square held a significant short position in both Ambac and MBIA, making the model an ideal illustration of how an extremely sophisticated, incentivized market participant might be analyzing the firms' CDO exposures. Yet in neither the model itself nor the ensuing public relations battle that was waged between the insurers and Pershing Square was reference made to the considerable amount of publicly-available lower-tier data concerning the CDO securities. Rather, the

11. See infra Part III.C (chronicling market reactions to downgrades of multi-sector CDOs in 2008).

12. See infra Part IV.A. (analyzing short selling activity in Ambac's common stock during 2008).

13. See infra Part IV.C. (analyzing Pershing Square Capital's Open Source Model). 
brief debate surrounding the model's accuracy focused primarily on general, and often inaccurate, assumptions made about the cash flow rights and subordination provisions relating to the individual $\mathrm{CDO}$ securities. ${ }^{14}$ In short, while the episode suggests investors might use position-level disclosures to conduct a more detailed portfolio analysis of the insurers, it was hardly an illustration of how investors in financial firms might use more enhanced, granular disclosures of a CDO's architecture and composition to engage in real-time portfolio analysis.

In combination, the results from both the event studies and the Pershing Square analysis are strongly suggestive that enhancing derivative disclosures, by itself, is unlikely to reduce the uncertainty that often plagues analysis of a firm's exposure to complex credit derivatives such as CDOs. On the contrary, the sharply divergent experience of Ambac with respect to the PG\&E downgrades in 2001 and its CDO downgrades in 2008 indicates that even ordinarily efficient capital markets may be marked by considerable inefficiency when it comes to processing publicly-available information relating to these types of derivatives. This conclusion is further supported by even a cursory review of Pershing Square's remarkable attempt to conduct a real-time assessment of the CDO portfolios insured by Ambac and MBIA. While the firms insured a total of just 59 multi-sector CDOs, their performance ultimately depended on the cash flows of approximately 400 inner-CDOs and over 3000 mortgage-backed securities. ${ }^{15}$

At the same time, however, analysis of the monoline experience during the Financial Crisis also provides some hope that enhanced derivative disclosures can facilitate greater awareness of a firm's exposure to credit risk. Despite the challenge of assessing the CDO portfolios of Ambac and MBIA, Pershing Square nevertheless undertook the process, ultimately producing a portfolio analysis that was virtually prophetic in light of the losses eventually suffered by the firms. ${ }^{16}$ That it did so using only a portion of the considerable public information available for each CDO highlights the power of even a partially accurate analysis of complex derivatives to enhance market efficiency, albeit on a more delayed and ad hoc basis than one might desire. As regulators in the United States and around the world continue to assess optimal derivatives disclosure regimes, the results of this study thus give reason for some optimism that enhanced derivative disclosures may result in greater market discipline, but they also highlight the very real challenge that information complexity poses for efficient asset pricing in even the most liquid of capital markets.

This Article proceeds as follows. Part II provides general background on the monoline insurance industry and the unique set of disclosure obligations that applied to insurers' portfolios of insured bonds and CDOs. Part III commences the empirical investigation of the effectiveness of enhanced derivatives disclosure by conducting a series of single firm event studies on the stock price of Ambac. As shown in Part III, the relatively simple, direct way in which the firm's investors responded to PG\&E's downgrade in 2001 was notably missing during the Financial Crisis of 2008. In light of these results, Part IV turns to an analysis of the manner in which more sophisticated

14. See id.

15. See infra note 166 and accompanying text (summarizing Pershing Square's findings regarding the CDO portfolios of Ambac and MBIA).

16. See infra note 171 and accompanying text (highlighting the difference between Ambac's estimated and actual CDO losses). 
investors might have responded to these downgrades, focusing on bi-monthly shortselling data, daily price movements in the CDS market, and a detailed analysis of the Pershing Square financial model. Part $\mathrm{V}$ follows with a discussion of the potential implications of these findings on the future of derivatives disclosure. Part VI concludes.

\section{BACKGROUND: MONOLINE INSURERS AND THEIR DERIVATIVE DISCLOSURES}

That the fate of the monoline industry could become interwoven with the fate of complex credit derivatives is, in many ways, a remarkable development in light of the industry's simple beginnings. The origins of the industry go back only to 1971 when MGIC Investment Corp.-an insurer focusing on private residential mortgage insurance-convinced an Alaska municipality to purchase an insurance guaranty policy to "wrap" (or guarantee) the principal and interest on the municipality's general obligation bonds. ${ }^{17}$ The purpose of the transaction was to enable the municipality to lower its overall cost of borrowing based on the fact that its payment obligations would thereafter be guaranteed by MGIC, which had a slightly higher credit rating. At the same time, the credit risk incurred by MGIC was likely to be extremely low. ${ }^{18}$ In particular, the taxing authority of the municipality could provide reliable cash flows while its governmental status made an actual payment default a remote possibility. ${ }^{19}$ With this basic business model established, the ensuing years witnessed several insurers emerge whose sole line of business was to mimic this transaction with other municipalities, thus giving rise to the "monoline" industry.

Although municipal insurance would remain at the heart of the industry, the low margins on this single line of business eventually encouraged monolines to expand in the late 1980 s into non-taxpayer supported, project-based public finance transactions such as those financing hospitals, utilities, and toll roads. ${ }^{20}$ Similar considerations also encouraged their entry during the 1990s into the structured finance market where they guaranteed the principal and interest payments on the debt securities issued by assetbacked securitization vehicles. ${ }^{21}$ In this regard, the monolines were aided by the explosive growth in securitizations during the late 1990s and 2000s, which typically required some form of external credit enhancement in order to successfully market the senior notes in a securitization. ${ }^{22}$ Among the alternative sources of external credit enhancement, monolines represented ideal providers due in part, to the fact that no

17. See James P. McNichols, Monoline Insurance \& Financial Guaranty Reserving, CASUALTY ACTUARIAL SOC'Y, 233 (2003), available at http:/www.casact.org/pubs/forum/03fforum/03ff231.pdf (discussing the origins of the financial guaranty industry).

18. Id.

19. More specifically, any municipal bond that suffered a significant deterioration in its credit quality would most likely be renegotiated, meaning that any potential insurance loss would be limited to the cost of carry, that is, the cost of bridge financing as the debt was renegotiated. See McNichols, supra note 17, at 23334 (explaining why municipal bonds, theoretically, would never fail to pay interest or principal).

20. Id. at 265 .

21. Id. at 266 .

22. See Mahesh K. Kotecha, The Role of Financial Guarantees in Asset-Backed Securities, in ISSUER PERSPECTIVES ON SECURITIZATION 93 (Frank J. Fabozzi ed., 1998) (discussing the demand for financial guarantee insurance in typical securitization transactions). 
monoline insurer had ever experienced a single ratings downgrade. ${ }^{23}$ Moreover, from a monoline's perspective, the risk profile of the senior notes in a securitization fit within the traditional business model of wrapping only investment grade credits having a remote risk of credit loss. ${ }^{24}$ When securitization markets turned to issuing CDOs that were themselves backed by asset-backed securities, monoline insurers were thus wellpositioned to offer senior and super-senior protection on CDO transactions. ${ }^{25}$

With respect to the insurers' public disclosures concerning these exposures, the firms' unique status as financial guarantee companies resulted in their investors having access to a considerable amount of information regarding the insured securities. Like all U.S. insurance companies, monoline insurers are subject to the accounting and reporting requirements established by the National Association of Insurance Commissions (NAIC) which require, among other things, detailed quarterly and annual disclosures concerning an insurer's holdings of debt and equity securities. ${ }^{26}$ In addition, monoline insurers have historically also provided details about their largest public finance, structured finance, and healthcare exposures by means of quarterly "operating supplements" made available on their company websites. ${ }^{27}$ As monoline insurers expanded to write significant policies on CDOs after 2005, these latter disclosures provided investors in monoline insurance companies with considerable information concerning an insurer's book of CDO exposures. This was especially true by the autumn of 2007 as the primary monoline insurers began to disclose the specific name, exposure amount, and rating for each insured CDO position. ${ }^{28}$

23. See id. at 97 .

24. See Paul Severs, Monoline Insurer Financial Guarantees: Expanding the Investor Horizon, in ASSET SECURITISATION AND SYNTHETIC STRUCTURES: INNOVATIONS IN THE EUROPEAN CREDIT MARKETS 239 (2006) (discussing monoline insurers' "zero loss" or "remote loss" underwriting standard and noting that "for structured deals ... the monolines require that they be rated by two rating agencies at investment-grade level").

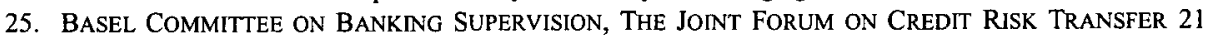
(2004), available at http://www.bis.org/publ/joint13.pdf.

26. See, e.g., Ambac Financial Group, Inc., Annual Report (Form 10-K) 89 (April 9, 2010), available at http://ir.ambac.com/phoenix.zhtml?c=80774\&p=IROL-sec\&secCat01.1_rs=21\&secCat01.1_rc=10 [hereinafter Ambac 2009 10-K Report] (describing statutory accounting rules applicable to Ambac). The NAIC is the primary organization by which the country's state insurance regulators seek to promote uniform national policy concerning insurance regulation. See The NAIC's History and Background, NAIC, http:/www.naic.org/ index_about.htm (last visited on Aug. 8, 2010) (describing the NAIC's primary responsibility). In this capacity, the NAIC publishes the Accounting Practices and Procedures Manual which details the quarterly and annual filings that insurers must make with their state insurance regulators. Among the disclosures required to be made is Schedule D of the Annual Statement Blank, which requires an itemized list of an insurer's investment securities, including security name, CUSIP number, acquisition cost, and current value. See, e.g., AMBAC ASSURANCE CORP., ANNUAL STATEMENT OF THE AMBAC ASSURANCE CORPORATION OF MADISON IN THE STATE OF WISCONSIN, FOR THE YEAR ENDED DECEMBER 31, 2009 E10-E16, available at http://www.ambac.com/pdfs/Statutory/Ambac\%20Annual\%20Statement\%202009.pdf [hereinafter AMBAC 2009 ANNUAL STATEMENT].

27. See, e.g., AMBAC ASSURANCE CORP., 2009 QUARTERLy OPERATING SUPPLEMENT Q4 22-23 (2009), available at http:/www.ambac.com/pdfs/OperatingSupplements/4q09_OpSup.pdf (listing largest public finance, domestic healthcare, and structured finance exposures); MBIA, INC., QUARTERLY OPERATING SUPPLEMENT 41 (2009), available at http:/files.shareholder.com/downloads/ABEA-363IPQ/ 1023999954x0x392482/4512EB2B-7886-41D7-A8C3-14543642FFD2/Q42009operatingsupplement_revised64-2010_.pdf (listing the largest structured finance exposures).

28. In the case of Ambac, for instance, its Operating Supplements redacted the names of most CDO exposures until August 2007 when it first released the names of its individual CDO positions. See, e.g., AMBAC 
In addition to these portfolio-level or "upper-tier" derivative disclosures, investors in monoline insurance companies also had available to them a considerable amount of more granular, "lower-tier" information pertaining to each disclosed CDO position. The reason was due to a remarkable coincidence of timing. As noted above, monoline insurers began to write significant protection on multi-sector CDOs in approximately $2005,{ }^{29}$ the same year in which the European Union's Prospectus Directive ${ }^{30}$ took effect. Adopted in 2003, the Prospectus Directive was aimed at harmonizing the requirements governing the offering documents that could be used for securities offerings within the European Union. ${ }^{31}$ Under the Directive, a prospectus for securities being approved in one EU Member State would provide a "passport" to enable these securities to be offered to the public or listed in any other EU Member State without further approval of the offering document. ${ }^{32}$

A key component of the Prospectus Directive was set forth in Article 14, which provided that once approved by a Member State, a prospectus must be made "available to the public" through "publication." 33 While each Member State could specify the precise means by which this requirement was satisfied, Article 14 listed a variety of approved methods, including publication in "an electric form on the website of the regulated market where the admission to trading is sought." ${ }^{34}$ Like the Securities Act of 1933, the Directive contained a number of exemptions, such as for securities offerings that were limited to certain institutional investors, offerings to fewer than 100 natural persons in any one Member State, or offerings having a denomination of less than EUR 50,000.35 No exemption existed, however, for any offering of securities that were to be admitted to trading on a regulated market within the European Union.

As it turned out, this last provision ensured that most of the multi-sector CDOs issued after 2005 were subject to the publication requirements of the Prospectus Directive. The reason stemmed from the way in which CDOs were typically marketed to

\footnotetext{
AsSuRANCE CORP,, 2007 QUARTERly OPERATING SUPPlement Q2 25 (2007), available at http://www.ambac.com/pdfs/OperatingSupplements/2q07_OpSup.pdf. Beginning with its Operating Supplement for December 31, 2007, Ambac thereafter included this information for each CDO tranche it had insured. See, e.g., AMBAC ASSURANCE CORP., 2007 QUARTERly OPERATING SUPPLEMENT Q3 26 (2008), available at http://www.ambac.com/pdfs/OperatingSupplements/3q07_OpSup.pdf (listing Ambac's largest structured finance exposures and largest international finance exposures).

29. See supra note 8 and accompanying text (noting the growing role of monoline insurers after 2005 in guaranteeing CDO debt obligations). With respect to Ambac, for instance, it wrote all but $\$ 780$ million of its $\$ 29$ billion of policies covering multi-sector CDOs between 2005 and 2007. Ambac 2007 10-K Report, supra note 9 , at 59 . Similarly with respect to MBLA, almost $75 \%$ of its $\$ 30$ billion of exposure to multi-sector CDOs was written from 2005 to 2007. MBIA 2007 10-K Report, supra note 9, at 67.

30. See Council Directive 2003/71, On the Prospectus to Be Published When Securities Are Offered to the Public or Admitted to Trading and Amending Directive 2001/34/EC, 2003 O.J. (L 345) 6 [hereinafter Prospective Directive] (describing the Prospectus Directive).

31. See Roberta S. Karmel, Regulating European Markets: Transactional Perspectives on Current Market Abuse Initiatives, 26 U. PA. J. INT'L ECON. L. 379, 388-93 (2005) (discussing the background, purposes, and effects of the Prospective Directive).

32. The directive was part of the EU's broader Financial Services Action Plan announced in 1999, which had as its overall goal the establishment of an integrated financial market within Europe. Id. at 380-84.

33. See Prospectus Directive, supra note 30 , at 76 (describing the publication requirement).

34. Id.

35. Id. at Art. 3(2).
} 
institutional investors. In light of strong demand among European and international investors for structured credit products, underwriters of CDOs generally conducted an international offering of their notes to a variety of Asian and European institutional investors. ${ }^{36}$ For many of these investors, however, government regulations or internal investment criteria required that they invest, wholly or largely, in securities that had been admitted to a regulated market in the European Union. ${ }^{37}$

This de facto requirement that a CDO list on a regulated EU market also created strong incentives for enterprising EU Member States to compete for the listing fees and other benefits that attached to becoming a jurisdictional choice for CDOs that were required to list its securities for these marketing-related purposes. By the late 1990s it was clear that Ireland would be the victor in this race due to a combination of favorable tax provisions for international structured finance vehicles as well as domestic policies enacted during the 1980 s aimed at making Dublin an international center for legal and financial expertise concerning securitizations. ${ }^{38}$ With the implementation of the Prospectus Directive in 2005, it was therefore the website of the Irish Stock Exchange (ISE) that would be the publication outlet for virtually all of the CDO prospectuses that were issued at about the time that the monoline insurance companies entered into the market for multi-sector CDOs. Indeed, in the case of the 59 CDOs insured by Ambac and MBIA, an electronic copy of the prospectus for almost all of them can be found at the ISE website located at http://www.ise.ie/.

For an investor interested in analyzing one of these CDO positions, review of the CDO's prospectus provided a considerable amount of both legal and financial information. Because the content of these prospectuses was regulated by the Prospectus Directive, there was also a considerable amount of consistency among different CDO offering documents. As in a registered U.S. public offering, the prospectuses provided both a summary of terms pertaining to the offering (e.g., aggregate amount offered,

36. See, e.g., Mara Der Hovanesian, Taking Risk to Extremes: Will Derivatives Cause a Major Blowup in the World's Credit Markets?, BUSINESSWEEK, May 23, 2005, available at http://www.businessweek.com/ magazine/content/05_21/b3934099_mz020.htm ("Derivative demand has been ... profound in Europe among investors seeking high income from synthetic CDOs that are top-rated by S\&P and other agencies.").

37. For instance, European occupational pension providers were required to invest predominantly in securities admitted to EU regulated markets, while EU life insurers were prohibited from investing more than ten percent of their total gross assets in securities that were not admitted to such markets. See FRESHFIELDS Bruckhaus Deringer, The Prospectus Directive and ITS IMPlementation IN THE UK, 2-3 (2004), http://www.freshfields.com/publications/pdfs/practices/9790.pdf (discussing investment considerations for European institutional investors); see also UK Regulator Bids to Ease E.U. Prospectus Requirements, DERIVATIVES WEEK, Oct. 22, 2004, at 4 (noting that "institutional investors often require listed paper, which has to be issued under the disclosure regime of the EU prospectus directive"). Not surprisingly, the fact that CDOs would effectively become subject to this new disclosure burden, including in some cases the requirement that the issuer comply with International Financial Reporting Standards, unleashed a wave of criticism against the "one-size-fits-all" disclosure obligation contained in the Prospectus Directive. See, e.g., US, Europe Debate Disclosure, STRUCTURED FIN. INT'L, March 29, 2004 (noting that the directive "has drawn criticism because of its one size fits all approach for securitisations and other securities"). It also prompted widespread speculation that non-EU securities issuers would flee regulated EU markets in favor of non-EU markets, such as those offered by the Channel Islands. See, e.g., id. (noting that non-EU issuers of debt securities may have strong incentives to delist to non-EU jurisdictions such as the Cayman Islands, Switzerland, or the Channel Islands); Prospectus Horribilis?, STRUCTURED FIN. INT'L, Aug. 8, 2005, (same).

38. See Cormac Kissane, Securitizations in Ireland, in SECURITIZATIONS: LEGAL AND REgUlatory IsSUES 21-1 to 21-15 (2006) (discussing evolution of Ireland's financial services sector). 
tranches of securities, collateral characteristics, and the terms of the notes and any material agreements) as well as a discussion of risk factors pertaining to an investment in the notes. A prospectus would also include a summary of the indenture governing the notes, which would be especially relevant for a monoline insurer and its investors. In particular, because monolines wrapped the senior-most tranche of a CDO, this section of the prospectus would provide details regarding the subordination, overcollateralization, and control provisions that were designed to protect these securities from experiencing any loss of principal. ${ }^{39}$

The Prospectus Directive did not require the specific itemization of the collateral securities or any periodic filings for most CDOs, but review of a prospectus generally provided interested investors with the means by which they could locate this data within other public repositories of information. Specifically, each prospectus was required to identify the trustee for the CDO who was generally required under the terms of the indenture to make available to investors monthly remittance reports concerning the CDO's general financial performance and any payments made by the CDO to noteholders, administrators, or hedge counterparties. ${ }^{40}$ These reports also included detailed information concerning the identity and performance of all underlying collateral securities. ${ }^{41}$ Significantly, because a CDO's notes might be periodically traded, by 2005 most indenture trustees had established online investor reporting systems on their websites, thereby enabling even non-investors to access this information. ${ }^{42}$

Thus, for an investor in a monoline insurer in late 2007 and early 2008, the simple disclosure each quarter of an itemized list of insured CDO exposures could enable her to engage in a potentially robust analysis of each exposure's underlying credit risk. To be sure, the disclosures were hardly as convenient to access as those made by a reporting company under the Securities Exchange Act of 1934-the enterprising investor would ultimately have to stitch together a patchwork of different documents to undertake the analysis. Yet for an investor leery of the potential liability of these exposures, the fact remains that the information was in the public domain, requiring only an Internet connection to access. Whether or not this was a sufficient condition for its effective utilization constitutes the main inquiry for the remainder of this Article.

39. For a discussion of how these provisions operated in practice, see infra at notes 169-70 and accompanying text.

40. Commission Regulation 809/2004, Annex IX § 9.1, Annex XV § 5.1, (2004 O.J. (L 149)), available at http://ec.europa.eu/internal_market/securities/docs/prospectus/reg-2004-809/reg-2004-809_en.pdf

41. See generally Susan J. Macaulay, The Role of the Securitisation Trustee, in Global SECURITISATION AND STRUCTURED FINANCE (2004) (discussing the duties of a securitization trustee).

42. See, e.g., WELLS FARGO, CTSLink, http://www.ctslink.com/ (website for Wells Fargo trustee services); Global Corporate Trust Reporting, BANK OF NEW YORK MELLON, https://gctinvestorreporting. bnymellon.com/Home.jsp (last visited Nov. 12, 2010) (website for Bank of New York Mellon trustee services). This process was facilitated as well by the concentrated market structure of the indenture trustee market. Among trustees of asset-backed securities in 2003, for instance, Deutsche Bank, Bank of New York Mellon, JP Morgan Chase, and Wells Fargo held market shares of 20.4\%, 15.3\%, 10.9\%, and 10.5\%, respectively. See Macaulay, supra note 41, at 1-2 (discussing the growth of the securitization market). Most of these remittance reports were also made available online through the "AbsNet" subscription service offered by Lewtan Technologies, Inc., a firm specializing in the collection of securitization data. See AbsNet http://www.absnet.net/home.asp. 


\section{UTILIZATION OF DERIVATIVE DISCLOSURES: EVENT STUDY ANALYSIS}

As a preliminary means to examine whether investors used the aforementioned disclosures to assess a monoline insurer's derivative exposures, I turned to an event study framework. For this purpose, I focused on the manner in which the derivative disclosures affected the asset prices of one of the largest monoline insurers, Ambac Financial. In addition to being one of the industry's largest insurers of multi-sector CDOs, Ambac's shares also traded on the New York Stock Exchange, thus providing an ideal environment to examine how a generally semi-strong efficient marketplace might process derivative disclosures.

\section{A. Event Study Framework: Overview}

Use of an event study framework was motivated largely by the basic relationship between a financial guarantor's equity value and changes in the credit risk of the thirdparty debt on which it has written credit protection. In general, to the extent that there is an increase in the risk that an insured credit will default on its principal and interest payments, there will be a corresponding increase in the likelihood the insurer will incur a payout on the relevant insurance policy. ${ }^{43}$ Accordingly, an increase in the default probability of a significant exposure should be expected to result in a decrease in the equity value of the financial guarantor given the increased probability that the insurer will be forced to realize a loss on the policy. Equally important, deterioration in the credit quality of an insured exposure will also have an adverse impact on the insurer's statutory capital as the higher likelihood of a loss payout will erode its existing loss reserves. In some cases, a significant deterioration in the credit quality of an insured position might even force a financial guarantor to increase its statutory capital, which could entail considerable dilution for the firm's existing equity investors.

Given this basic relationship, an event study analysis can potentially provide a useful means to examine how effectively investors process public disclosures concerning a monoline's insurance exposures. A central idea informing the event study methodology is that in semi-strong efficient markets, the price of a publicly traded security reflects all public information on the present value of the future cash flows associated with the ownership of that security. ${ }^{44}$ Unexpected news of a material event affecting the cash flows of the issuing firm-such as the sudden increase in the credit risk of a monoline's major bond exposure-should therefore result in an immediate price reaction as investors adjust their reserve prices for its equity securities to accommodate the new information. For the same reason, the absence of a market reaction to this type of news may suggest evidence of information inefficiencies. For instance, even if a security ordinarily trades in a semi-strong efficient market, discerning the informational value of an announcement

43. Although financial guarantors will ordinarily reinsure a portion of this potential loss, the total amount of reinsurance has historically been only a fraction of the total amount of insured exposures. For instance, McNichols reports that during the ten-year period from 1990 to 1999 , monoline insurers ceded only $20 \%$ of their insurance premiums to reinsurers, which covered approximately $16.2 \%$ of expected losses. See McNichols, supra note 17, at 272 (discussing the role of reinsurance within the financial guarantee industry).

44. See Jonathan R. MACEY, AN INTROduction to MOdERn Financial TheORY 38-40 (2d ed. 1998) (providing an overview of the Efficient Capital Market Hypothesis). 
may be so complex as to impair investors' ability to rapidly assess it. ${ }^{45}$

This approach to examining the efficiency with which investors process a monoline insurer's portfolio disclosures, however, necessarily requires a reliable measure for a sudden change in the default probability of an insured credit. A promising candidate in this regard is the announcement of a multi-notch downgrade in an exposure's credit rating by either Standard \& Poor's (S\&P) or Moody's-the two largest credit rating agencies. ${ }^{46}$ While the nomenclature differs, both S\&P and Moody's use a system of approximately two-dozen notched ratings to reflect an issuer's likelihood of failing to make all principal and interest payments as required, which they periodically review while the debt is outstanding. ${ }^{47}$ For instance, a bond that maintained a rating of AAA by S\&P (approximately the same as a rating of Aaa by Moody's) would reflect a bond issue that $\mathrm{S} \& \mathrm{P}$ believes has the most remote probability of default. In contrast, a bond that was rated $\mathrm{BB}+$ or lower would generally reflect a non-investment grade credit for which there would be significant default risk. ${ }^{48} \mathrm{~A}$ rating of $\mathrm{C}$ would reflect a bond that was in imminent danger of defaulting. ${ }^{49}$

While credit rating agencies generally require that monolines limit their insurance exposure to investment-grade credits, 50 Ambac has occasionally insured credits that experienced a one-day downgrade from their original investment grade ratings to ratings that are below (often well below) investment grade. Of course, the most significant instances of these downgrades occurred during the spring and summer of 2008 with respect to Ambac's portfolio of multi-sector CDO exposures, but such downgrades, while uncommon, also occurred in other, less exotic areas of its portfolio. In particular, monolines' expansion into non-taxpayer supported, public finance transactions, such as debt issued by hospitals, airports, and utilities, brought with it greater exposure to the risk of private sector debt. ${ }^{51}$ As a result, even before the Financial Crisis, most monoline insurers had experienced the occasional multi-notch downgrade of a significant debt

45. See Ronald J. Gilson \& Reinier H. Kraakman, The Mechanisms of Market Efficiency, 70 VA. L. REV. 549,567 (1984) (noting that certain types of new information may require a longer time lag for "'full reflection' in price because [the information's] narrower distribution will force a qualitatively more circuitous form of price equilibration").

46. Although Fitch Ratings also rates certain bonds, it ranks a distant third behind S\&P and Moody's with regard to the number of CDOs rated from 2005 to 2008. For instance, of the six CDOs examined in Part III.C, Fitch rated only two, while both S\&P and Moody's rated all six. Given its smaller role in the ratings market, Fitch is therefore generally excluded from the event study that follows. Assessment of its rating actions on the two CDOs it rated, however, is considered infra in note 110. Data on downgrade announcement dates was obtained from Bloomberg.

47. See STANDARD \& POOR's, Guide to CREDIT RATING EsSEntlals 10 (2009), available at http://www2.standardandpoors.com/spf/pdf/fixedincome/SP_CreditRatingsGuide.pdf (describing S\&P's credit ratings); About Moody's Ratings, MOODY's, http://v3.moodys.com/ratings-process/Ratings-Definitions/002002 (last visited Oct. 3, 2010) (describing Moody's credit ratings).

48. See Long Term Bond Ratings, BONDSONLINE, http:/www.bondsonline.com/asp/research/ bondratings.asp (last visited Oct. 8, 2010) (defining both S\&P and Moody's ratings).

49. Id.

50. See McNichols, supra note 17, at 235 (discussing insurance criteria for monoline insurers). State insurance regulations also limit monolines to insuring debt that has been rated by one of the major credit rating agencies. $I d$.

51. See id. at 267 (noting that monoline "insurers have gravitated to an in-force risk portfolio that contains higher potential default frequency and loss severity characteristics with more uncertain correlations than those observed in the past"). 
exposure in its portfolio of public finance transactions. ${ }^{52}$ The existence of these multinotch downgrades within Ambac's structured finance portfolios and within its lesscomplex, ordinary bond portfolios provides an opportunity to examine how closely investors tracked the credit risk of individual, disclosed positions within these two domains.

To be sure, using publicly-announced credit downgrades in an event study naturally suffers from an important limitation-namely, investors may be making their own assessment of a credit's default probability in advance of an official credit rating downgrade. While this possibility is explored in more detail in Part III.B, several factors suggest that even where the market might anticipate a credit's downgrade, its formal announcement is still likely to constitute a news event for the monoline insurer that wrapped it. For one, in the course of rating a debt security, CRAs obtain a considerable amount of nonpublic, confidential information concerning the issuer that may make an announced ratings decision especially informative. Similarly, even if the market anticipates a ratings downgrade, the formal announcement may resolve lingering uncertainty over the extent and magnitude of an issuer's credit deterioration. This is especially true where the downgrade is more extensive than market analysts were predicting as was often the case when an insured credit experienced a one-day, multinotch downgrade. Perhaps for these reasons a number of empirical studies have found significant negative abnormal returns in the stock price of firms upon the announcement of a credit rating downgrade of their debt. ${ }^{53}$

Moreover, the highly regulated nature of financial guaranty insurance also serves to amplify the importance of formal credit rating actions within their portfolios. Due to the potential liquidity and solvency risk of writing unfunded bond insurance, regulatory capital requirements are calibrated to track closely the credit risk within a monoline insurer's portfolio, for which official credit ratings have come to serve an important

52. In addition to PG\&E, for instance, monolines also insured the debt of the Alleghany health system, which filed for bankruptcy in 1998. See Tracy Sacco, Investors Mull Fate of Allegheny Health, Pa. Bonds, REUTERS NEWS, July 21, 1998 (describing credit deterioration of bonds issued by the Alleghany health system); see also U.S. Municipal Rating Transitions and Defaults, 1986-2009 STANDARD \& POOR's, (Mar. 11, 2009), http://www2.standardandpoors.com/portal/site/sp/en/eu/page.article/3,3,3,0,1204844871307.html\#ID1095 (summarizing historical rating transitions of U.S. public finance issuers) (last visited Oct. 8, 2010).

53. See, e.g., John R. M. Hand et al., The Effect of Bond Rating Agency Announcements on Bond and Stock Prices, 47 J. FIN. 733, 741 (1992) (finding a decline in stock returns after a credit rating downgrade); Robert W. Holthausen \& Richard W. Leftwich, The Effect of Bond Rating Changes on Common Stock Prices, 17 J. Fin. ECON. 57, 57 (1986) (same); Michael J. Ho \& Robert S. Harris, Market Reactions to Messages from Brokerage Ratings Systems, 54 FIN. ANALYSTS J. 49, 53 (1998) (same); Jeremy C. Goh \& Louis H. Ederington, Is a Bond Rating Downgrade Bad News, Good News, or No News for Stockholders, 48 J. FiN. 2001, 2001 (1993) (finding a decline in stock returns only after downgrades that result from a reevaluation of the firm's or industry's financial prospects); Ilia D. Dichev \& Joseph D. Piotroski, The Long-Run Stock Returns Following Bond Ratings Changes, $56 \mathrm{~J}$. FN. 173, 173 (2001) (finding negative returns of $10-14 \%$ in the first year following downgrades, with results "especially pronounced for small, low-credit-quality firms"); Richard A. Followill \& Terrence Martell, Bond Review and Rating Change Announcements: An Examination of Informational Value and Market Efficiency, $21 \mathrm{~J}$. FN. \& ECON. 75, 75 (1997) (finding that announcements of downgrades cause declines in stock returns, but that actual downgrades results in a negligible change); Louis Ederington \& Jeremy Goh, Bond Rating Agencies and Stock Analysts: Who Knows What When?, 33 J. FiN. QUANT. ANALYSIS 569, 569 (1998) ("[W]hile most bond downgrades are preceded by declines in actual forecast earnings, both actual earnings and forecasts of future earnings tend to fall following downgrades."). 
role. $^{54}$ Specifically, the availability of a significant amount of time-series data concerning credit ratings and their associated default frequencies has facilitated the development of credit mapping to determine economic and regulatory capital within both the insurance and the banking industries. ${ }^{55}$ Under this system, the economic and regulatory capital needed for a portfolio of credits (or for a portfolio of insured credits) is determined by inferring their default probabilities from the long-term default probabilities of similarly rated bonds. For this reason, the official announcement of a credit downgrade for an insured bond will often have the practical effect of signaling an insurer's need to increase its economic and regulatory capital. In sum, a multi-notch downgrade of a large insured exposure would appear to provide an important signal of an adverse change in a monoline's financial position. Therefore, to the extent that investors effectively process a monoline's portfolio-level disclosures to price its equity securities, one should expect to see a significant market reaction in connection with these types of downgrades.

\section{B. Market Reactions to the Downgrade of Pacific Gas \& Electric in 2001}

As a first step in investigating the efficiency with which investors processed derivative disclosures, I examined the stock price reaction of Ambac to one of the most widely followed credit crises involving insured public finance bonds: the 2001 bankruptcy of Pacific Gas \& Electric (PG\&E). Focusing on the credit turmoil of PG\&E in 2001 illustrates three important points. First, as noted above, using the credit downgrade of an ordinary bond issuer provides a useful starting point for examining how complexity might affect the efficiency with which investors process derivative disclosures. That is, if investors use a monoline's disclosure of ordinary bond insurance to make calibrated assessments of the insurer's derivative credit risk but show less evidence of processing the risk of a disclosed CDO position, the additional complexity of a CDO may be to blame.

Second, the PG\&E experience also provides a unique opportunity to examine the extent to which the credit downgrade of an insured position, even if anticipated, constitutes material news for the monoline insurer that wrapped it. As previously noted, the announcement of a formal credit downgrade may provide a potentially weak proxy for a sudden increase in an issuer's default risk if the market has already anticipated the downgrade. Given the intensity with which the market followed PG\&E's credit deterioration in 2001, a significant market reaction to its ultimate ratings downgrade would be strongly suggestive of the "news" value of a ratings announcement even when an issuer's credit condition is widely followed.

Lastly, the PG\&E credit crisis also presents one of the few instances where both Ambac and its primary competitor, MBIA, wrapped the same distressed security. Moreover, the public disclosures of Ambac and MBIA made clear that both firms insured the debt securities of PG\&E, ${ }^{56}$ albeit their disclosed exposures were significantly

54. See infra notes 113-16 and accompanying text (discussing statutory capital requirements applying to Ambac).

55. See, e.g., JOHN C. HULL, RISK MANAGEMENT AND FINANClAL INSTITUTIONS 291-92 (2010) (describing a method for calculating a rated bond's unconditional one-year default probability based on Moody's historical data of cumulative one-year default rates for various ratings).

56. See infra notes 80-81 and accompanying text (discussing Ambac's and MBIA's exposures to PG\&E 
different in notional value. These differential exposures permit an additional dimension on which to investigate whether enhanced disclosure can help resolve marketplace uncertainty regarding firms' exposure to credit derivatives. Specifically, if disclosure of derivative credit risk can reduce marketplace uncertainty, investors' response to the PG\&E downgrades should have been both swift and well-calibrated to reflect the firms' differing exposures to PG\&E described in their portfolio disclosures. To examine this effect, the event study described below therefore includes an analysis of both Ambac's and MBIA's stock price reactions following the announcement of negative changes in PG\&E's credit condition.

For purposes of conducting the event study, I first identified five dates of importance relating to PG\&E's credit crisis. In general, the company's credit turmoil was rooted in a significant escalation of wholesale electricity prices during the summer of 2000 combined with regulatory price caps that limited the amount that PG\&E could charge its electricity consumers. ${ }^{57}$ An unusually hot June and July further contributed to the dilemma as consumers dramatically increased electricity consumption, forcing PG\&E to purchase ever larger quantities of electricity from the wholesale electricity spot market at prices that they were unable to recoup by charging higher retail prices. ${ }^{58}$ Consequently, by the end of August 2000, PG\&E's undercollections for the year-the gap between what it paid for power and what it could charge customers - were reported to have reached $\$ 2$ billion, and California utilities had begun a significant campaign to lift consumer rate caps that were set by the California Public Utilities Commission (CPUC). ${ }^{59}$

Despite this lobbying effort, PG\&E announced in an 8-K filing on September 14, 2000 that the CPUC had denied its request to release the utility from certain rate-setting regulations and that the company may be required to write off its $\$ 2.2$ billion undercollection deficit as a one-time charge against earnings. ${ }^{60}$ The announcement prompted Moody's to undertake the first formal ratings action later that evening by changing its outlook on the company from "stable" to "negative." 61 It was a decision that turned out to be extremely predictive as PG\&E's undercollections balance would reach $\$ 2.7$ billion by the end of the month, prompting the company to announce that " $[t]$ he massive and rapid buildup in PG\&E's uncollected wholesale power costs is not just a cost recovery problem, it is a severe cash flow problem as well." 62 Two months later, PG\&E's undercollections had continued to grow and with it, speculation that the situation might drive the company into bankruptcy. By late December, the company itself appeared to agree: in making a request to the CPUC for a $26 \%$ rate increase, PG\&E's general counsel

bonds).

57. See Carolyn Said, The Energy Crunch: A Year Later, S.F. CHRON., Dec. 24, 2001, at Al (explaining the 2000-2001 energy crisis in California).

58. Id.

59. See Chris Kraul, Power Exchange Complaints Heat Up as Prices Soar, L.A. TiMEs, Sept. 9, 2000, at $\mathrm{Cl}$ (discussing the consequence of rising energy costs on California power utilities).

60. PG\&E, Current Report (Form 8-K) (Sept. 13, 2000), available at http://www.sec.gov/Archives/edgar/ data/75488/000100498000000031/0001004980-00-000031-0001.txt.

61. David Lazarus, PG\&E Warning Lowers Debt Rating - New Strategy in Battle over Power Payments, S.F. CHRON., Sept. 15, 2000, at B1, available at http://www.sfgate.com/cgi-bin/article.cgi?f=/c/a/2000/09/15/ BU75171.DTL.

62. Steve Johnson, PG\&E Wants Consumers to Repay $\$ 2.7$ Billion in Summer Power Costs, SAN JosE MERCURY NEWS, Oct. 5, 2000. 
stressed that the "financial survival of PG\&E, and possibly the survival of the California economy, hangs in the balance." 63 Not surprisingly, the statement unleashed widespread concern that the company was on the brink of filing for bankruptcy. ${ }^{64}$

On January 4, 2001, the CPUC agreed to a temporary rate increase, subject to review following an audit of the company's finances. ${ }^{65}$ Nonetheless, that same day S\&P lowered its ratings on the company's bonds from A+ to BBB-, S\&P's lowest investment grade rating. ${ }^{66}$ Moody's followed suit on January 5 by lowering its ratings to Baa3 from A3. ${ }^{67}$ On January 17 , both S\&P and Moody's further cut PG\&E's credit rating to CC and $\mathrm{Caa} 2$, respectively-ratings that were well into junk territory. ${ }^{68}$ PG\&E would ultimately file for bankruptcy protection on April 6, 2001. ${ }^{69}$ The following table summarizes the foregoing events relating to PG\&E's deteriorating credit condition:

Table 1: Event Dates Related to PG\&E's Deteriorating Credit Condition

\begin{tabular}{|l|l|}
\hline Date & Event \\
\hline $9 / 14 / 00$ & $\begin{array}{l}\text { After trading closes on 9/14/00, Moody's changes its credit outlook on } \\
\text { PG\&E from "stable" to "negative" following PG\&E's profit warning. }\end{array}$ \\
\hline $1 / 4 / 01$ & S\&P downgrades PG\&E to BBB-. \\
\hline $1 / 17 / 01$ & S\&P and Moody's further cut PG\&E's credit rating to junk status. \\
\hline $4 / 6 / 01$ & PG\&E files for bankruptcy protection. \\
\hline
\end{tabular}

With these dates established, daily stock price returns for Ambac and MBIA were then collected from the Center for Research in Security Prices (CRSP). Data was collected for the entire 2000 calendar year as well as the first six months of 2001.

Following conventional event study methodology, the return-generating process for each insurer's daily stock price return $\left(R_{t}\right)$ on day $t$ was initially assumed to take the following form:

$$
R_{t}=\alpha+M K T_{t} \cdot \beta+A_{t}
$$

where $\alpha$ is a firm-specific constant, $M K T_{t}$ is the return on the CRSP equally-weighted portfolio for day $t, \beta$ is a firm-specific coefficient measuring how the firm's stock price has varied historically with changes in $M K T_{t}$, and $A_{t}$ is the firm's abnormal return for

63. See, e.g., David Lazarus, PG\&E Seeking 26\% Jump in Rates, S.F. CHRON., Dec. 28, 2000, at A1 (discussing PG\&E's attempt to secure rate increases).

64. See id.

65. PG\&E, Current Report (Form 8-K) (Jan. 5, 2001), available at http://www.sec.gov/Archives/edgar/ data/75488/000100498001000004/0001004980-01-000004-0001.txt [hereinafter PG\&E Current Report].

66. See S\&P Lowers Pacific Gas \& Electric, CA Related Issues to BBB-, BUS. WIRE, Jan. 5, 2001 (detailing the downgrade).

67. See Ed Mendel \& Dean Calbreath, State Considers Takeover Option; Transmission System Would Be Purchased, Plants Built, THE S.D. UNION-TRIB., Jan. 6, 2001, at A1 (noting PG\&E downgrade by Moody's).

68. PG\&E Current Report, supra note 65 . The downgrade also triggered a default under PG\&E's $\$ 850$ million revolving line of credit, but no amounts were outstanding at the time.

69. See Reynolds Holding, PG\&E Files for Bankruptcy: THE BATTLE AHEAD, S.F. CHRON., April 7, 2001 (describing the implications of PG\&E's bankruptcy filing). 
day $t$. The abnormal return, $A_{t}$, thus reflects the component of the observed return that cannot be explained by the other components of the model. Using ordinary least squares regression, both $\alpha$ and $\beta$ were estimated jointly using a 100-day trading window that ended ten days prior to the event date of interest. ${ }^{70}$ The end result was a simple onefactor model of each insurer's stock price return for a given day based on the return of the market portfolio for that same day.

Abnormal returns for the event dates were then calculated using this market model. Rearranging the terms of equation (1) reveals that the abnormal return for a particular event day was simply the observed return for that day less the return that would have been expected from the market model:

$$
A_{t}=R_{t}-\left(\alpha+M K T_{t} \cdot \beta\right)
$$

To account for the fact that the market response to an event may spread into subsequent trading days, I also calculated the abnormal stock return for the day after each event date. Lastly, to assess the statistical significance of these abnormal returns, I used Gelbach, Helland, and Klick's sample quantile methodology for single firm event studies. ${ }^{71}$

Panel A of Table 2 sets forth the results. ${ }^{72}$ On each of the four event dates the stock price of both Ambac and MBIA declined significantly as would be expected if investors were calibrating each firm's financial position based on its exposure to PG\&E's credit risk. Initially, the stock price of both companies appeared to be affected about the same, with Ambac's suffering slightly more than MBIA's. For instance, on September 15 (the first trading day on which investors could respond to PG\&E's profit warning and Moody's change in PG\&E's outlook) Ambac experienced a weakly significant, negative one-day abnormal return of approximately 3\% while MBIA experienced a weaker, insignificant $2 \%$ decline. By the following day, however, both companies had experienced a significant negative two-day cumulative abnormal return of approximately $6 \%$. On January 4 (the day of the first official downgrade of PG\&E) both companies experienced even stronger negative abnormal returns, with Ambac's negative abnormal return occurring both faster and having a greater magnitude and statistical significance than MBIA's.

70. This is a common estimation period in event study methodology. See Sanjai Bhagat \& Roberta Romano, Empirical Studies of Corporate Law, in 2 HANDBOOK OF LAW AND ECONOMICS 945, 947, 915 (A. Mitchell Polinsky \& Stephen Shavell eds., 2007) (explaining standard event study methodology). In unreported regressions, I also used an estimation period of 200 days before the relevant event date and obtained similar results to those presented in Tables 2 and 3 below. See infra Tables 2 and 3. Additionally, to address the concern that the relationship between an insurer and the market portfolio might have changed due to the event of interest, I also estimated models using estimation periods of 100 and 200 days after the relevant event date and a pooled model having an estimation period that included the 100 days before and 100 days after the relevant event date. Lastly, to address the possibility that certain estimation periods might have biased, inflated standard errors where an estimation period for an event date includes other event dates (e.g., the estimation period for $1 / 17 / 01$ includes returns for both $9 / 14 / 00$ and $1 / 4 / 01$ ), I also ran regressions using estimation periods that were purged of any other event dates. In each case, the abnormal returns and their statistical significance were substantially the same as those presented in Tables 2 and 3.

71. See Jonah B. Gelbach et al., Valid Inference in Single-Firm, Single-Event Studies (Robert Day School of Economics and Finance Research Paper No. 2009-17, July 31, 2009) 19-21, available at http://papers.ssm.com/sol3/papers.cfm?abstract_id=1442222 (describing sample quantile methodology).

72. See infra Table 2. 
Table 2: Abnormal Returns to Ambac and MBIA Associated with the 2001 PG\&E Bankruptcy ${ }^{73}$

\begin{tabular}{|c|c|c|c|c|c|c|c|c|}
\hline $\begin{array}{l}\text { Event } \\
\text { Date: }\end{array}$ & $\begin{array}{r}9 / 15 \\
\text { (Moody } \\
\text { Ou }\end{array}$ & $\begin{array}{l}2000 \\
\text { Revises } \\
\text { ook) }\end{array}$ & \multicolumn{2}{|c|}{$\begin{array}{c}1 / 4 / 2001 \\
\text { (Downgrade to } \\
\text { BBB-) }\end{array}$} & \multicolumn{2}{|c|}{$\begin{array}{c}1 / 17 / 2001 \\
\text { (Downgrade } \\
\text { to Junk) }\end{array}$} & \multicolumn{2}{|c|}{$\begin{array}{c}4 / 6 / 2001 \\
\text { (Bankruptcy } \\
\text { Filing) }\end{array}$} \\
\hline \multicolumn{9}{|c|}{ Panel A: One-Factor Market Model } \\
\hline & Ambac & MBIA & Ambac & MBIA & Ambac & MBIA & Ambac & MBIA \\
\hline \multirow[t]{2}{*}{$\begin{array}{c}\text { Abnormal } \\
\text { Return }\end{array}$} & $\begin{array}{l}-0.03^{*} \\
(0.03)\end{array}$ & $\begin{array}{l}-0.02 \\
(0.02)\end{array}$ & $\begin{array}{c}-0.07^{* * *} \\
(0.02)\end{array}$ & $\begin{array}{l}-0.04^{* *} \\
(0.02)\end{array}$ & $\begin{array}{l}-0.02 \\
(0.02)\end{array}$ & $\begin{array}{l}-0.02 \\
(0.02)\end{array}$ & $\begin{array}{l}-0.04^{*} \\
(0.03)\end{array}$ & $\begin{array}{c}-0.09^{* * *} \\
(0.02)\end{array}$ \\
\hline & {$[-0.04,0.05]$} & $-0.04,0.04$ & {$[-0.04,0.06]$} & $-0.04,0.04]$ & {$[-0.04,0.06]$} & {$[-0.03,0.04]$} & {$[-0.05,0.05]$} & {$[-0.05,0.04]$} \\
\hline \multirow[t]{2}{*}{$\begin{array}{l}\text { CAR } \\
(0,+1)\end{array}$} & $\begin{array}{l}-0.06^{* *} \\
(0.03)\end{array}$ & $\begin{array}{l}-0.06^{* *} \\
(0.03)\end{array}$ & $\begin{array}{l}-0.07^{* *} \\
(0.03)\end{array}$ & $\begin{array}{l}-0.05^{*} \\
(0.03)\end{array}$ & $\begin{array}{l}-0.02 \\
(0.03)\end{array}$ & $\begin{array}{c}-0.08^{* *} \\
(0.03)\end{array}$ & $\begin{array}{l}-0.03 \\
(0.04)\end{array}$ & $\begin{array}{c}-0.09^{* *} \\
(0.03)\end{array}$ \\
\hline & {$[-0.05,0.06]$} & $-0.05,0.08$ & {$[-0.06,0.06]$} & $-0.06,0.08]$ & {$[-0.06,0.06]$} & {$[-0.06,0.04]$} & {$[-0.07,0.06]$} & {$[-0.07,0.04]$} \\
\hline
\end{tabular}

Panel B: Two-Factor Industry Model

\begin{tabular}{ccccccccc}
\hline & Ambac & MBIA & Ambac & MBIA & Ambac & MBIA & Ambac & MBIA \\
\hline Abnormal & -0.02 & -0.01 & 0.00 & $0.03^{* *}$ & 0.01 & 0.00 & 0.00 & $-0.06^{* * *}$ \\
Return & $(0.02)$ & $(0.01)$ & $(0.01)$ & $(0.01)$ & $(0.01)$ & $(0.01)$ & $(0.01)$ & $(0.01)$
\end{tabular}

$[-0.03,0.04][-0.02,0.03] \quad[-0.03,0.03][-0.02,0.03][-0.03,0.03][-0.02,0.02] \quad[-0.03,0.02][-0.02,0.03]$

$\begin{array}{ccccccccc}\text { CAR } & -0.04^{*} & -0.04^{* *} & 0.01 & 0.03^{*} & 0.01 & -0.04^{* *} & 0.01 & -0.05^{* *} \\ (0,+1) & (0.02) & (0.02) & (0.02) & (0.02) & (0.02) & (0.02) & (0.02) & (0.02) \\ & {[-0.04,0.04]} & {[-0.03,0.05]} & {[-0.03,0.03]} & {[-0.03,0.03]} & {[-0.03,0.03]} & {[-0.03,0.03]} & {[-0.03,0.03]} & {[-0.04,0.03]}\end{array}$

The last two event days also reveal significant negative abnormal returns for the insurers; however, it was the stock of MBIA rather than Ambac that suffered the most with each negative announcement about PG\&E's credit condition. In fact, news of PG\&E's downgrade to junk status resulted in a significantly negative $8 \%$ two-day CAR for MBIA, but only an insignificant negative 2\% CAR for Ambac. Both firms also

73. This table reports the one- and two-day abnormal returns for Ambac and MBIA for each of the four event dates involving an announcement of a negative change in the credit risk of PG\&E in connection with its 2001 bankruptcy. Panel A estimates abnormal returns for each insurer using a one-factor market model based on the returns to the CRSP equal-weighted index during the 100 trading days ending ten days before the relevant event date. Panel $B$ estimates abnormal returns for each insurer using a two-factor market model based on the returns to the CRSP equal-weighted index and returns to an equally-weighted portfolio composed of the publicly-traded stock of all financial guarantee companies. ${ }^{*}=$ statistically significant at $90 \%$ confidence; ${ }^{* *}=$ statistically significant at $95 \%$ confidence; $* * *=$ statistically significant at $99 \%$ confidence. Statistical significance was determined using Gelbach et al., supra note 71. Standard errors appear in parentheses; fivepercent sample quantiles (two-tailed) appear in brackets. 
experienced significantly negative one-day abnormal returns on the day of PG\&E's bankruptcy filing, but again, the negative 9\% abnormal return for MBIA was more than double the magnitude of Ambac's.

Overall, the speed and magnitude of these negative abnormal returns following each event date are broadly consistent with a marketplace that was quickly processing new information about PG\&E's credit condition to update their equity valuations of MBIA and Ambac. Moreover, PG\&E's financial condition was under considerable scrutiny during this time period by regulators, analysts, and the media, yet the formal credit rating downgrades remained an important source of news regarding PG\&E's credit condition and the insurers' exposure to it. ${ }^{74}$ This conclusion is further supported by the absence of any other material news stories involving either MBIA or Ambac surrounding the four event dates. Nor did there appear to be any other major credit problems involving any of their other credit exposures during the time of these four events. In short, the story of PG\&E's credit crisis suggests that a significant credit rating downgrade of an insured position can constitute a news event for a monoline insurer even when the downgrade might be anticipated by the market.

At the same time, however, these results say little about the extent to which the abnormal returns for MBIA and Ambac on each event date were appropriate in light of each firm's actual credit exposure to PG\&E. In particular, the seemingly abrupt shift in the relative magnitude of the abnormal returns for Ambac compared to MBIA could easily reflect a marketplace that is simply speculating about the firms' exposures to a known credit risk. Indeed, the financial turmoil following the collapse of Lehman Brothers and AIG revealed that uncertainty about exposure to credit derivatives can quickly erode investor confidence in an entire industry sector. To what extent did public disclosures about Ambac's and MBIA's insurance policies lead to a more refined assessment of their exposure to a potential PG\&E default?

As noted previously, the operating supplements released each quarter by MBIA and Ambac ordinarily list the amount of the companies' largest insurance exposures. In the case of the California energy crisis, however, neither firm had an exposure to a California utility that was large enough to be listed in the supplement prior to September 2000. Nor was there a reliable means to obtain accurate information about the amount of their relative exposures from other public sources. In particular, while bond issuers often disclose in their offering documents whether an offering is insured by a financial guarantee policy, much of the PG\&E debt that was insured by MBIA and Ambac was raised through the California Pollution Control Financing Authority. ${ }^{75}$ The public offering was therefore exempt from the mandatory reporting requirements of the Securities Act of $1933 .{ }^{76}$ Equally important, bond insurers periodically sell insurance on

74. See supra notes 57-69 (detailing media coverage of PG\&E's financial deterioration in 2000 and 2001).

75. In re PG\&E, Case No. 01-30923DM (N.D. Cal. Apr. 6, 2001); MBIA Inc., Current Report (Form 8-K) (Jan. 30, 2001), available at http://www.sec.gov/Archives/edgar/data/814585/000095013001000473/ 0000950130-01-000473-0001.txt.

76. See 15 U.S.C. $\$ 77 \mathrm{c}(\mathrm{a})(2)$ (2006) (exempting securities issued by any state or municipality). In theory, an enterprising investor could obtain the original offering circular-referred to as an Official Statement-by means of one or more private repositories of Official Statements. Specifically, Rule 15c2-12 (which the SEC promulgated pursuant to its authority to regulate underwriters) prohibits an underwritten offering of municipal 
the secondary market, meaning that even where a bond was uninsured upon its original issuance, a financial guarantor could subsequently become liable on it. $^{77}$ For these reasons, the growing California energy crisis eventually sparked exactly the type of speculation regarding derivative credit risk exposure among monoline insurers that would later plague the entire financial sector in the fall of 2008. This was especially true for the two largest monolines, Ambac and MBIA, who were widely reported to have insured the debt of PG\&E as well as that of Southern California Edison (SoCal Edison), which was also suffering from the power crisis. ${ }^{78}$

In light of this uncertainty, the negative 6\% two-day CAR on September 15 for both Ambac and MBIA was hardly surprising. More difficult to explain, however, are the abnormal returns for the companies on January 4. By this time, speculation regarding the companies' exposure to PG\&E and SoCal Edison had prompted the insurers to disclose their total net exposure to the two utilities. The announcements, which were made by means of company press releases on December 21 , revealed that only MBIA had a material exposure to the utilities. ${ }^{79}$ In aggregate, MBIA announced that it had a total net exposure of $\$ 590$ million relating to $P G \& E$ bonds and $\$ 438$ million relating to SoCal Edison bonds. ${ }^{80}$ Ambac, in contrast, announced total net exposures of just $\$ 72.6$ million and $\$ 75.1$ million, respectively. ${ }^{81}$ Given these disclosures on December 21 , the abnormal returns for Ambac and MBIA on January 4, 2001 (the date of PG\&E's initial downgrade) therefore appear backward-it was MBIA, not Ambac, that had the greater credit exposure to $\mathrm{PG} \& \mathrm{E}$.

After January 4, however, the market appears to have appreciated MBIA's heightened exposure to PG\&E, as reflected in the company's greater negative abnormal returns on both January 17 (PG\&E's downgrade to junk status) and April 6 (PG\&E's bankruptcy). Exactly why this would be the case as of January 17 but not on January 4 remains puzzling. Overall, the stock market in which shares of Ambac and MBIA traded satisfied the conditions generally required for semi-strong market efficiency-namely strong liquidity, the presence of sell-side equity analysts that followed each stock, and the

securities unless it is accompanied by an accurate "official statement" summarizing the offering, which must be made publicly available through certain approved private repositories. See 17 CFR $\S 240.15$ c2-12(b) (2010) (requiring underwriters of municipal securities to obtain and review the issuer's official statement); Telephone Interview with Robert Feyer, Partner, Orrick, Herrington \& Sutcliffe LLP (Jan. 6, 2010) [hereinafter Feyer Interview] (on file with author) (describing municipal securities offering practices). The patchwork of private repositories that developed in response to Rule 15c2-12 was largely made obsolete by the creation in 2008 of a centralized database of municipal disclosures known as EMMA (Electronic Municipal Market Access). Id.

77. Feyer Interview, supra note 76.

78. See, e.g., Califormia Utilities Pose Minimal Risk to Bond Insurers' Ratings, BUS. WIRE, Dec. 22, 2000 (noting that MBLA, Ambac, Financial Security Assurance, and Financial Guaranty Insurance Co. "all have varying degrees of exposure to Pacific Gas \& Electric and Southern California Edison").

79. See MBIA Expects Southern California Edison and Pacific Gas \& Electric to Continue to Make Debt Service Payments On MBIA-Insured Bonds, BUS. WIRE, Dec. 21, 2000 (discussing MBIA's exposure to PG\&E and SoCal Edison); Ambac Financial Group has Insured Exposure to Southern California Edison and Pacific Gas \& Electric, BUS. WIRE, Dec. 21, 2000 (discussing Ambac's exposure to PG\&E and SoCal Edison).

80. See MBIA Expects Southern California Edison and Pacific Gas \& Electric to Continue to Make Debt Service Payments On MBIA-Insured Bonds, supra note 79.

81. See Ambac Financial Group has Insured Exposure to Southern California Edison and Pacific Gas \& Electric, supra note 79. 
ability of investors to take short positions-albeit on a limited basis. ${ }^{82}$ Likewise, the companies' December 21 disclosures occurred in the very public medium of a press release. Of course, other positive announcements regarding MBIA - or other negative announcements regarding Ambac-could provide a potential explanation for the January 4 abnormal returns. A search on Factiva for all articles including "MBIA" or "Ambac" published on January 3,4 , or 5 , however, revealed only 12 news stories involving either company that did not involve the California energy crisis. None of them discussed subjects that were likely to produce a significant abnormal return for Ambac or MBIA. ${ }^{83}$

Rather, a review of all news stories published in January 2001 and that mentioned at least one of the insurers indicates that simple latency may be the best explanation. Despite the December 21 press releases, few news articles referenced the disclosed exposures in the days that followed. Instead, references to each firm's potential exposure to PG\&E and SoCal Edison continued to be phrased in general terms. For instance, an article published on January 5 in The Bond Buyer stated simply that "MBIA Insurance Corp. and Ambac Assurance Corp. each have insured significant amounts of SCE and PG\&E debt." 84 A week later, however, S\&P announced a downgrade to junk of $\$ 300$ million of bonds issued by the California Independent System Operator, which MBIA also insured. The announcement appeared to trigger a significant increase in the number of news articles devoted to discussing the insurers' exposure to California electric utilities. Whereas only two such news stories appeared in the first 11 days of January, six appeared between January 11 and January $17 .{ }^{85}$ In all of them, MBIA's specific exposure to PG\&E was now mentioned, with the Dow Jones Newswire concluding on January 17 that "MBIA surely holds the bag on more insured debt in the state than any of its rivals." $" 86$

The delayed processing of the December 21 disclosures was further confirmed when I controlled for the historic correlation of MBIA's and Ambac's returns with other firms in the financial guarantee industry. To do so, I estimated a market model in which I regressed each firm's return on the CRSP equally-weighted index (as before) as well as on the returns on an equally-weighted portfolio that included the stocks of all publicly traded financial guarantee companies. The results are presented in Panel B of Table $2 .{ }^{87}$ Overall, the analyses reveal considerable correlation between the daily returns of the industry portfolio and the returns of each firm. In the case of Ambac, for instance, the $R^{2}$ of the basic market model using the September 15 event date indicates that only $9 \%$ of

82. See generally Gilson \& Kraakman, supra note 45 (describing conditions for semi-strong market efficiency).

83. The one possible exception was a news story released on January 3,2001 discussing a dispute between Providence, Rhode Island and Moody's regarding Moody's decision to downgrade the city's bonds-which were insured by MBIA - to junk status. Wayne Peacock, Rhode Island Mayor Fires Back at Moody's Over City's Downgrade to Junk Status, THE BOND BUYER, Jan. 3, 2001, at 6 . To the extent this story might affect MBIA's stock price returns however, it would most likely be in the opposite direction than the one needed to explain the peculiar abnormal returns of January $4,2001$.

84. Deborah Finestone, California IOUs Hope the State Can Help Restore Credit Ratings, THE BOND BUYER, Jan. 5, 2001, at 1 available at http://www.bondbuyer.com/news/-132151-1.html.

85. This search was conducted on Factiva and replicated on Lexis.

86. Pat Maio, S\&P Lowers ISO's \$300M Rating, MBLA Troubles Mount, Dow JoNES NEws SERVICE, Jan. $17,2001$.

87. See supra Table 2. 
the variance in Ambac's daily returns was attributable to their correlation with returns for the overall market, compared to $56 \%$ in the industry portfolio model. The effect of using the industry portfolio was similarly strong with MBIA, with the $R^{2}$ increasing from $5 \%$ in the single-factor model to approximately $60 \%$ in the industry portfolio model.

Given this strong historic correlation, the results in Panel B are especially informative of how efficiently the market was processing MBIA's and Ambac's disclosures of their PG\&E exposures. Although the returns of both Ambac and MBIA were closely tied to their industry peers' returns, Panel B shows that both firms continued to experience a significant negative two-day CAR on September 15 even after controlling for this correlation. As noted previously, the market appeared to have very little detailed information concerning the insurers' exposure to the California energy crisis at this time, and the results are consistent with a marketplace that appeared to be speculating that any liability relating to PG\&E would be experienced by the two largest, most prominent monoline insurers. The January 4 results similarly suggest a marketplace engaged in speculation about which insurers had exposure to the California energy crisis. Although the overall market return that day was $1.1 \%$, the monoline industry portfolio and Ambac both fell by $6 \%$. Moreover, a search on Factiva revealed no news events surrounding January 4 that would explain such an isolated decline in the stock price of financial guarantee companies. Surprisingly, MBIA - who had by this point disclosed that it was a primary bond insurer on both PG\&E and SoCal Edison debt ${ }^{88}$-fell by only $3.25 \%$, resulting in a positive abnormal return of $3 \%$ after controlling for the correlation of MBIA's stock price with the rest of the monoline industry.

Consistent with the prior results, however, the marketplace appears to have appreciated MBIA's greater exposure to PG\&E on the subsequent event dates, with MBIA experiencing a negative abnormal return on each day. In comparison, the returns for both Ambac and the industry portfolio are negative, but only slightly so. In other words, although there might still be residual uncertainty concerning other firms' exposure to a PG\&E bankruptcy, MBIA's immediate exposure was now directly reflected in its significant, negative abnormal returns compared with the returns of its peer firms.

Overall, the PG\&E experience thus seems to confirm in many ways the promise of more granular derivative disclosures. In contrast to the uncertainty and speculation about insurers' exposure to a PG\&E default in September 2000, Ambac's and MBIA's December 21 disclosures ultimately resulted in a more refined and accurate assessment of the derivative credit risk posed by PG\&E's deteriorating credit condition. At the same time, however, the PG\&E experience also suggests the limitations of relying on disclosure to reduce the uncertainty concerning this risk in times of economic crisis. Notwithstanding the considerable attention surrounding the California energy crisis, it nevertheless took over two weeks for its effects to appear accurately in the abnormal returns of either Ambac or MBIA. To the extent the PG\&E crisis represents a best case scenario to examine the potential for derivative disclosures (i.e., a clear public announcement of derivative exposures and a relatively isolated, widely followed credit

88. See MBIA Expects Southern California Edison and Pacific Gas \& Electric to Continue to Make Debt Service Payments on MBIA-Insured Bonds, supra note 79 (discussing MBIA's exposure to PG\&E and SoCal Edison). 
event of the underlying security), it also provides a reason to expect less from these disclosures in the more complex domain of structured finance.

\section{Market Reactions to Downgrades of Multi-Sector CDOs in 2008}

To examine how investors might use granular, portfolio-level disclosures of more complex derivative securities, I conducted a similar series of event studies on the stock price of Ambac, using as the event of interest the first announcement of a multi-notch credit downgrade of a significant disclosed CDO position it insured. As discussed previously, by 2007 Ambac and MBIA had each written a considerable amount of insurance on the senior-most tranche of the debt issued by multi-sector CDOs. ${ }^{89}$ With respect to Ambac, its portfolio consisted of 28 positions having a total notional exposure of approximately $\$ 29$ billion. ${ }^{90}$ As in the case of PG\&E, the insured securities were originally rated investment grade upon issuance ${ }^{91}$ but in many cases were subsequently downgraded to below investment-grade status beginning in early $2008 . .^{92}$ In contrast to the California energy crisis, however, the downgrades were considerably more extreme than the downgrade of PG\&E's debt securities. By the end of 2008, all of the exposures within Ambac's CDO portfolio would lose their AAA rating, with six exposures being downgraded on a single day from the highest rating of AAA or Aaa to a rating that was below investment grade-a decline of more than nine notches. ${ }^{93}$ The first downgrade of PG\&E, by contrast, was just five notches from A+ to BBB. ${ }^{94}$ Moreover, Ambac's economic exposure to each of these six CDOs was considerable, with a total notional exposure of over $\$ 8$ billion. ${ }^{95}$ Given the consequences of PG\&E's downgrade on Ambac and MBIA, one might therefore expect a similar reaction on these even more extreme downgrades. ${ }^{96}$

89. See supra note 9 and accompanying text (discussing Ambac's and MBIA's aggregate exposure to multi-sector CDOs).

90. Ambac Financial Group, Inc., Annual Report (Form 10-K) 76 (March 16, 2009), available at http://www.sec.gov/Archives/edgar/data/874501/000119312509054939/d10k.htm [hereinafter Ambac 2008 10K REPORT] (analyzing Ambac's exposure to multi-sector CDOs).

91. See Ambac Assurance Corp., ANNUAl Statement of the AmbaC Assurance Corporation of MADISON IN THE STATE OF WISCONSIN, FOR THE YEAR ENDED DECEMBER 31, 200714.9 (2008), available at http://www.ambac.com/pdfs/Statutory/Ambac\%20Annual\%20Statement\%202007.pdf ("All twenty-eight CDO of ABS exposures were executed at an initial credit rating (both ACP and at least one major rating agency) of Triple A.").

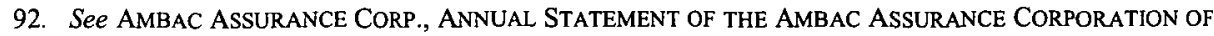
MADISON IN THE STATE OF WISCONSIN, FOR THE YEAR ENDED DECEMBER 31, 200814.9 (2009), available at http://www.ambac.com/pdfs/Statutory/Ambac\%20Annual\%20Statement\%202008.pdf [hereinafter AMBAC 2008 ANNUAL STATEMENT] ("Since the third quarter of 2007, the major rating agencies have downgraded and put on watch for downgrade a significant number of RMBS and CDO of ABS, including securities guaranteed by Ambac.").

93. For each insured CDO position, I examined the position's rating history using Bloomberg.

94. See S\&P Lowers Pacific Gas \& Electric, CA Related Issues to BBB-, supra note 66 and accompanying text (detailing S\&P's downgrade of PG\&E).

95. See infra Table 3 for a summary of each position.

96. Likewise, to the extent that an insurer estimated economic capital by reference to value at risk, a simple calculation of $99.9 \%$ credit VaR for a AAA bond that was downgraded to BBB-would yield an increase in required economic capital that was two-times the capital increase required for a bond that was downgraded from $\mathrm{A}+$ to BBB-. For this purpose, I used the following one-year default frequencies: $0.001 \%$ for an AAA 
As in the case of the PG\&E downgrades, I examined the market reaction to each of these six downgrades in 2008 to assess how Ambac's investors were responding to the deterioration of its CDO portfolio. For each downgrade, I used the same event study framework as before. In this case, however, the event date of interest was the first day on which either S\&P or Moody's downgraded the specific tranche of notes that were insured by Ambac. As before, two separate market models were estimated based on the returns to the equal-weighted CRSP portfolio and the industry portfolio using a 100-day trading window that ended ten days prior to the event date of interest. I similarly used Gelbach, Helland, and Klick's sample quantile methodology to assess statistical significance. ${ }^{97}$

One important difference between this analysis and that of PG\&E, however, was the considerable amount of economic instability that plagued the financial sector throughout 2008. By the end of 2007 , rising default rates within the U.S. housing sector had already begun to focus attention on financial firms' exposure to mortgage-backed securities, and investors were especially swift to focus on monoline insurers following a series of negative earnings announcements by these firms in the fall of 2007.98 In the case of Ambac, its stock price lost more than half its value during the second half of October following an announcement that it would take a $\$ 743$ million loss for the third quarter of 2007 owing to mark-to-market adjustments in its credit derivatives portfolio. ${ }^{99}$ Similar mark-to-market losses adversely affected Ambac's earnings in 2008 while continuing to raise concerns about the company's ability to absorb them. ${ }^{100}$ To shore up its capital position, Ambac ultimately raised $\$ 1.5$ billion in March 2008 in a highly dilutive equity offering, ${ }^{101}$ but it was still downgraded that summer from AAA to AA by S\&P and from Aaa to $\mathrm{Aa} 3$ by Moody's. ${ }^{102}$ As discussed below, this whirlwind of events affecting Ambac during 2008 complicates the event study analysis.

Table 3 presents the results of the six studies. ${ }^{103}$ Overall, they reveal a mixed story about the efficiency with which investors were processing these significant downgrades within Ambac's derivatives portfolio. In the first, single-factor model, only two of the days experienced a significant negative abnormal return on the day of the event. These

credit, $0.06 \%$ for an A+ credit, and $0.31 \%$ for BBB-credit. Cf. Default, Transition, and Recovery: 2009 U.S. Corporate Default Study and Rating Transitions, STANDARD AND POOR's (July 15, 2010), http://www.standardandpoors.com/ratings/articles/en/us/?assetID=1245218127257 (noting AAA rated corporate issuers have an average 1-year default frequency of $0 \%, \mathrm{~A}+$ rated issuers have an average of $0.06 \%$, and $\mathrm{BBB}$ rated issuers have an average of $0.31 \%$ ).

97. As in the prior event study of the PG\&E bankruptcy, I also conducted the same series of unreported regressions discussed in supra note 70 to examine whether the results might change using different estimation periods. None of the results reported in Table 3 were materially different using these alternative estimations.

98. See, e.g., Dwight Cass, Mono a Mono, BREAKINGVIEwS.COM (Aug. 16, 2007) ("The market has pummeled stocks of firms like MBIA and Ambac on fears of big losses on the CDOs they have insured.").

99. See Matthew Hanson, Bond Insurers: Ambac Announces \$743M in Pre-Tax Losses; Derivatives Blamed, THE BOND BUYER, Oct. 12, 2007, at 7 (discussing Ambac's third quarter loss).

100. See Carolyn Murphy, Ambac Weighs Strategic Options, THE Dally DEAL, Jan. 23, 2008 (discussing Ambac's 2007 fourth quarter loss of $\$ 3.26$ billion and Moody's decision to put Ambac on review for possible downgrade).

101. See Michael Rudnick, Downgrades Plague Insurer, THE DAILY DEAL, Apr. 1, 2008 (discussing Ambac's equity financing).

102. See Yvette Shields, Kansas City Selling \$213M of Special Obligation Debt, THE BOND BUYER, July 10,2008 , at 5 (discussing downgrades of Ambac by S\&P and Moody's).

103. See infra Table 3. 
results, however, are almost certainly the result of other negative news about Ambac that was released on those days. On January 17, 2008, for instance, Moody's announced that it had placed Ambac on review for possible downgrade from Aaa notwithstanding Ambac's plans to raise over $\$ 1$ billion in new capital. ${ }^{104}$ That day's $51 \%$ drop in Ambac's stock price prompted comment by numerous analysts, all of which attributed the sharp drop to Moody's announcement. ${ }^{105}$ Likewise, on November 5, 2008, the negative one-day $33 \%$ abnormal return most likely stemmed from Ambac's earnings announcement released that day in which it reported a third-quarter loss of $\$ 2.4$ billion. ${ }^{106}$ As before, analysts commenting on Ambac's stock price on November 5, 2008 made no reference to the specific downgrade of the CDO exposure but instead focused on the company's earnings announcement. 107

104. Dakin Campbell, Rating Agencies Add to Insurers' Woes: Rating Agency Cites "Growing Concern," THE BOND BUYER, Jan. 18, 2008, at 1.

105. See, e.g., Dan Seymour, Moody's Sinks Bond Insurance Stocks, Fox NEwS (Jan. 17, 2008), http://www.foxnews.com/wires/2008Jan17/0,4670,Bondinsurers,00.html (attributing significant drop in Ambac's stock price to Moody's announcement).

106. See Ambac Financial Group, Inc. Announces Third Quarter Net Loss of \$2,431.2 Million, BUS. WIRE, Nov. 5, 2008, available at http://findarticles.com/p/articles/mi_m0EIN/is_2008_Nov_5/ai_n30963967/ (reporting Ambac's announcement).

107. See Associated Press, Ambac Loses $\$ 2.43$ Billion in 3rd Quarter, SAN DiEgo UNION-TRIB., Nov. 5, 2008, http://legacy.signonsandiego.com/news/business/20081 105-0506-earns-ambacfinancialgroup.html (explaining Ambac's third-quarter loss). 
Table 3: Abnormal Returns to Ambac Associated with Major CDO Downgrades ${ }^{108}$

\begin{tabular}{|c|c|c|c|c|c|c|}
\hline Event Date: & $1 / 17 / 2008$ & $2 / 20 / 2008$ & $3 / 14 / 2008$ & $3 / 24 / 2008$ & $11 / 5 / 2008$ & $12 / 1 / 2008$ \\
\hline CDO Downgraded: & $\begin{array}{c}\text { Adams } \\
\text { Square } \\
\text { Funding II }\end{array}$ & $\begin{array}{l}\text { Ridgeway } \\
\text { Court } \\
\text { Funding II }\end{array}$ & $\begin{array}{c}\text { Kleros } \\
\text { Preferred } \\
\text { Funding VI }\end{array}$ & $\begin{array}{c}\text { Cairn High } \\
\text { Grade ABS } \\
\text { CDO II }\end{array}$ & $\begin{array}{c}\text { Duke } \\
\text { Funding } \\
\text { High Grade } \\
\text { III }\end{array}$ & $\begin{array}{c}\text { Tremonia } \\
\text { CDO } \\
2005-1\end{array}$ \\
\hline $\begin{array}{r}\text { Insured Amount } \\
\text { (millions): }\end{array}$ & $\$ 600$ & $\$ 1,950$ & $\$ 2,400$ & $\$ 819$ & $\$ 1,750$ & $\$ 825$ \\
\hline $\begin{array}{r}\text { Agency Making } \\
\text { Downgrade: }\end{array}$ & Moody's & $S \& P$ & $S \& P$ & Moody's & Moody's & Moody's \\
\hline $\begin{array}{r}\text { Downgrade in } \\
\text { Notches: }\end{array}$ & 11 & 11 & 16 & 11 & 10 & 12 \\
\hline $\begin{array}{r}\text { Resulting Credit } \\
\text { Rating: }\end{array}$ & $\mathrm{Ba} 2$ & BB & $\mathrm{CCC}+$ & $\mathrm{Ba} 2$ & Bal & $\mathrm{Ba} 3$ \\
\hline \multicolumn{7}{|c|}{ Panel A: One-Factor Market Model } \\
\hline Abnormal Return & $\begin{array}{c}-0.46^{* * *} \\
(0.06) \\
{[-0.14,0.13]}\end{array}$ & $\begin{array}{c}-0.02 \\
(0.13) \\
{[-0.20,0.17]}\end{array}$ & $\begin{array}{c}0.01 \\
(0.13) \\
{[-0.20 .0 .17]}\end{array}$ & $\begin{array}{c}-0.12 \\
(0.13) \\
([-0.20,0.17]\end{array}$ & $\begin{array}{c}-0.33^{* *} \\
(0.16) \\
{[-0.25,0.49]}\end{array}$ & $\begin{array}{c}0.00 \\
(0.17) \\
{[-0.29,0.49]}\end{array}$ \\
\hline $\operatorname{CAR}(0,+1)$ & $\begin{array}{c}-0.45^{* * *} \\
(0.10) \\
{[-0.17,0.20]}\end{array}$ & $\begin{array}{c}-0.04 \\
(0.21) \\
{[-0.34,0.26]}\end{array}$ & $\begin{array}{c}-0.03 \\
(0.15) \\
{[-0.19,0.28]}\end{array}$ & $\begin{array}{c}-0.12 \\
(0.22) \\
{[-0.35,0.28]}\end{array}$ & $\begin{array}{c}-0.43^{* *} \\
(0.24) \\
{[-0.27,0.57]}\end{array}$ & $\begin{array}{c}0.08 \\
(0.23) \\
{[-0.31,0.52]}\end{array}$ \\
\hline
\end{tabular}

\begin{tabular}{rcccccc}
\hline Panel B: Two-Factor Industry Model & \multicolumn{7}{c}{} \\
\hline Abnormal Retum & $-0.26^{* * *}$ & -0.03 & -0.02 & -0.11 & $-0.29^{* *}$ & 0.02 \\
& $(0.03)$ & $(0.06)$ & $(0.07)$ & $(0.08)$ & $(0.13)$ & $(0.13)$ \\
& {$[-0.07,0.08]$} & {$[-0.12,0.12]$} & {$[-0.12,0.14]$} & {$[-0.14,0.14]$} & {$[-0.19,0.37]$} & {$[-0.22,0.37]$} \\
CAR $(0,+1)$ & $-0.19 * * *$ & -0.05 & -0.08 & -0.04 & $-0.37^{* *}$ & 0.04 \\
& $(0.04)$ & $(0.09)$ & $(0.09)$ & $(0.10)$ & $(0.19)$ & $(0.19)$ \\
& {$[-0.09,0.07]$} & {$[-0.17,0.14]$} & {$[-0.14,0.19]$} & {$[-0.20,0.20]$} & {$[-0.19,0.46]$} & {$[-0.27,0.45]$}
\end{tabular}

108. This table reports the one- and two-day abnormal returns for Ambac associated with the announcement of a major ratings downgrade in 2008 of six CDO exposures insured by Ambac. For this purpose, a major downgrade is defined as involving a rating downgrade of at least ten notches. Panel A estimates abnormal returns for each announcement date using a one-factor market model based on the returns to the CRSP equal-weighted index during the 100 trading days ending ten days before the relevant date. Panel B estimates abnormal returns for each insurer using a two-factor market model based on the returns to the CRSP equal-weighted index and returns to an equally-weighted portfolio composed of the publicly-traded stock of all financial guarantee companies. $*$ = statistically significant at $90 \%$ confidence; $* *=$ statistically significant at $95 \%$ confidence; ${ }^{* * *}=$ statistically significant at $99 \%$ confidence. Statistical inference was determined using Gelbach et al., supra note 71 . Standard errors appear in parentheses; five-percent sample quantiles (two-tailed) appear in brackets. 
A search on Factiva indicated that the remaining four event dates lacked similar confounding announcements, but as Table 3 shows, Ambac's abnormal returns in the single-factor market model were insignificant. Among the four event dates, only March 24,2008 reveals anything close to a significant result due to the negative $12 \%$ single day abnormal return that day. By this time, however, Ambac's volatility had increased considerably, such that even a negative $12 \%$ abnormal return was within a single standard deviation of Ambac's average daily abnormal returns during the estimation window. Moreover, if the return on March 24 reflected an appreciation of the downgrade of the CDO (Cairn High Grade ABS CDO II) downgraded that day, it is puzzling why March 25 would reflect a slight positive abnormal return. In the case of PG\&E, its downgrades generally resulted in two days of significant, negative returns for Ambac. ${ }^{109}$

Similarly weak results appear when controlling for industry correlation in the twofactor industry model. Again, it is only March 24 that comes close to a significant negative abnormal return. Controlling for Ambac's correlation with its industry peers shows that Ambac's return that day was predicted to be $11 \%$ greater than it actually was. This negative abnormal return, however, was once again offset by a positive abnormal return the following day of approximately $7 \%$, resulting in a two-day CAR of $-4 \%$. If investors were using Ambac's CDO disclosures to make real-time valuations of the company, they were doing so in a way considerably less apparent than in the case of the PG\&E crisis. ${ }^{110}$

To be sure, there are a number of potential differences between the PG\&E credit deterioration and the Financial Crisis of 2008 that may account for the absence of any significant market reaction to these CDO downgrades. For one, the downgrade of an insured securitization exposure may represent a less material event than the downgrade of a corporate bond. Indeed, during 2007 and 2008, Ambac, AIG, and other firms with large derivative exposures to CDOs initially sought to reassure investors of their limited claims potential due to contractual protections that were embedded within the insured securitizations. ${ }^{111}$ These included, for instance, subordination provisions that required the securitization issuer to pay interest on senior tranches of securities before any payment

109. See supra Table 2 (providing two-day CARs for Ambac related to the deterioration of PG\&E's credit condition).

110. As discussed in supra note 46, Fitch Ratings also rated two of the six CDOs--Ridgeway Court Funding II and Duke Funding High Grade III. In both cases, Fitch announced multi-notch downgrades of each insured tranche of notes earlier than Moody's and S\&P, but no significant negative abnormal returns were observed on either date using any of the specifications discussed in the text. On the contrary, the date on which Fitch downgraded Ridgeway Court Funding II (November 12, 2007) resulted in Ambac experiencing a slightly significant one-day positive abnormal return of $4 \%$ under the single-factor model (Ambac's one-day abnormal return dropped to $0 \%$ in the two-factor model). Similarly, Ambac's one- and two-day abnormal returns were generally positive (although not statistically significant) on May 2, 2008, the date on which Fitch downgraded Duke Funding High Grade III. A Lexis search of news stories did not reveal any significant news announcements relating to Ambac on either date.

111. See, e.g., Joseph Cassano, President and CEO of AIG Financial Products, Statement at an American International Group Investor Meeting, Dec. 5, 2007 (Lexis News File) ("So, think about it. Losses are allocated sequentially. Our wrapped segment would only come into play if the very last dollar of the AAA tower proceeds are absorbed, and that absorption needs to be loss net of recovery. So, there's an awful lot of protection built into these transactions prior to any chance of our transactions being hit."); see also Letter from Gary Dunton, CEO, MBIA, to the Honorable Eric Dinallo, Superintendent of Insurance, State of New York (Feb. 11, 2008) (on file with author) [hereinafter MBIA Letter] (discussing MBLA's response to the Open Source Model). 
could be made on junior securities. Likewise, senior tranches were protected through cash flow and overcollateralization provisions that required an issuer to pay down the outstanding principal of the senior notes in the event the value of the CDO's assets relative to the face value of the notes fell below certain specified thresholds. The most senior note holders and firms that insured them also had various control rights in the event of a default that allowed them to protect the value of the notes-for instance, by liquidating the CDO. Consequently, the downgrade of Ambac's CDO portfolio might have signaled less payment risk than in the case of a simple bond.

This response, however, ignores the different ways in which the downgrade of a securitization position could adversely affect Ambac. With regard to payment risk, the foregoing arguments would be more compelling with respect to addressing concerns arising from the downgrade of a junior tranche that was subordinate to an insured position. The event dates used here, however, were the days on which the actual notes insured by Ambac were downgraded. Based on the rating agencies' own interpretation of their ratings, the official signal of the downgrade was thus the same as in the case of an ordinary bond. That is, the relevant CRA now believed there was an increase in the risk that note holders would experience a default in the payment of interest and principal. ${ }^{112}$

Moreover, the official downgrade of a securitization exposure triggered at least two immediate financial consequences for Ambac. First, as with traditional bond insurance, Ambac was required to set aside a statutorily defined amount of capital to cover its unexpected losses. ${ }^{113}$ In the case of insurance written on both traditional bonds and structured finance positions, these statutory capital requirements were expressly tied to an exposure's external credit rating. For instance, Article 69 of the New York Insurance Code-which applied to Ambac by virtue of its New York underwriting business ${ }^{114}$ obligated the company to maintain surplus to policyholders and contingency reserves in an amount that exceeded specified percentages of the aggregate net liability for certain exposures. In the case of insurance written on asset-backed securities, Ambac was required to have surplus of at least $0.666 \%$ of the aggregate net liability under guarantees of "investment grade asset-backed securities" and $2 \%$ of "non-investment grade assetbacked securities." 115 The definition of "investment grade" security for this purpose included an obligation that "has been determined to be in one of the top four generic lettered rating classifications by a securities rating agency acceptable to the superintendent," or an obligation that "has been identified in writing by such rating agency to be of investment grade quality." 116 The downgrade to below investment grade status of $\$ 8$ billion of Ambac's insured CDOs thus triggered an immediate increase in Ambac's statutory capital requirements.

112. See, e.g., Understanding Standard \& Poor's Rating Definitions 11, STANDARD \& POOR's (June 3, 2009)http://www2.standardandpoors.com/spf/pdf/fixedincome/Understanding_Rating_Definitions.pdf ("Issue ratings are an assessment of default risk, but may incorporate an assessment of relative seniority or ultimate recovery in the event of default.").

113. Ambac 2007 10-K Report, supra note 9, at 19.

114. Id. at 27.

115. See N.Y. INS. LAW $\S 6904$ (c)(1) (McKinney 2004) (listing aggregate risk limits). A virtually identical provision can be found in the NAIC's Model Financial Guaranty Insurance Act. See NAIC MODEL LAWS, REGULATIONS, AND GUIDELINES, 1626-1, § 4 (2008).

116. N.Y. INS. LAW $\S 6901$ (McKinney 2004). 
Equally important, the legal structure of Ambac's portfolio of insured positions also accentuated the financial impact on the company when an insured exposure was downgraded. As financial institutions began accumulating large amounts of super-senior CDO exposure within their trading books, they increasingly requested monoline insurers to structure insurance wraps on these positions in the form of credit default swaps rather than traditional financial guarantee policies. ${ }^{117}$ The reason for this demand stemmed from the fact that Statement of Financial Accounting Standards (SFAS) 133 required securities positions within a bank's trading book to be marked-to-market, and holding a CDS on the same securities created an off-setting mark-to-market hedge. ${ }^{118}$ To accomplish this structuring goal, Ambac therefore wrote most of its credit protection on multi-sector CDOs through a wholly-owned subsidiary, Ambac Credit Products, LLC (Ambac Credit), which in turn, executed each transaction as a credit default swap (CDS). ${ }^{119}$ Each CDS ultimately mimicked a traditional bond insurance policy insofar as it obligated Ambac Credit (whose financial obligations were insured by Ambac Financial) to cover any shortfalls in required interest or principal payments owing on a CDO note. 120

Because they took the form of derivative instruments for accounting purposes, however, Ambac's CDS contracts were also subject to derivative accounting under SFAS 133. ${ }^{121}$ This required, among other things, that changes in the fair value of the CDS be recorded on Ambac's income statement as unrecognized gain (or loss) in each accounting period, while their aggregate fair value was to be recorded on the company's balance sheet as a derivative liability. ${ }^{122}$ During 2007 and 2008, the dramatic drop in the value of these contracts was the principal reason for Ambac's significant losses during this time period. For instance, in contrast to a gain of $\$ 68.8$ million in 2006 , Ambac's CDS portfolio experienced a mark-to-market loss of $\$ 5.9$ billion in 2007 and $\$ 4$ billion in $2008 .{ }^{123}$ At the same time, these losses created a $\$ 10$ billion liability on Ambac's 2008 balance sheet and further eroded its regulatory capital. ${ }^{124}$

117. See MBIA, Inc., An Introduction to the Impact of "Mark to Market" Accounting on MBIA and Financial Guarantors, 2 (2007), available at http:/www.mbia.com/investor/publications/ MarktoMarketPrimer.pdf (describing MBIA's use of CDS to insure debt positions held by financial institutions subject to mark-to-market accounting).

118. Id.

119. Ambac 2008 10-K Report, supra note 90, at 136.

120. Id.

121. Id. at 137 .

122. See Financial Accounting Standards Board, Statement of Financial Accounting Standards No. 133, Accounting for Derivative Instruments and Hedging Activities (June 1998) (outlining accounting and reporting standards for derivative instruments); see also WALLACE ENMAN, MOODY's INVESTORS SERV., INC., REP. NO. 105498, SPECIAL COMMENT: INTERPRETING FINANCIAL GuARANTORS' MARK-TO-MARKET LOSSES (July 2008), available at http://www.ambac.com/pdfs/RA/Mark-to-MarketLosses_07-08-08.pdf (analyzing Ambac's mark-to-market losses).

123. Ambac 2008 10-K Report, supra note 90, at 121.

124. Id. at 120. Under statutory accounting rules, statutory surplus each year is reduced by Ambac's statutory net loss. See National association of INSURANCE COMmissioners, ACCOUNTING Practices \& PRocedures Manual as of March 2010: Statements of STAtUTORY ACCOUNTING PRINCIPLES No. 72, $\S$ 12 , at 72-4 (noting contribution of net income (loss) and unrealized capital gain (loss) to unassigned funds). Ambac's 2007 year-end statutory capital was $\$ 3.3$ billion, while its statutory net loss for 2008 was over $\$ 4$ billion. AMBAC 2008 ANNUAL STATEMENT, supra note 92, at 4. Absent Ambac's ability to raise additional 
Significantly, because Ambac's CDS contracts were privately negotiated and did not trade, Ambac determined these fair value adjustments by using a valuation model rather than quoted prices. ${ }^{125}$ In describing its model in its 2007 annual report, Ambac emphasized the important role played by its internal ratings, which closely tracked an exposure's external rating. ${ }^{126}$ In particular, to estimate the loss on a CDS contract, Ambac periodically monitored the extent to which the credit spread on an underlying reference obligation had increased over its credit spread at the inception of the CDS contract. Any increase in this spread was then used to estimate Ambac's loss on the transaction for the reporting period. No loss was recorded, however, until a ratings downgrade actually occurred. ${ }^{127}$ As a result, a formal ratings downgrade of an exposure would almost certainly portend a valuation adjustment by Ambac for the reporting period and a corresponding loss of earnings. As of December 31, 2007, for instance, Ambac noted that based on existing credit spreads, a one letter downgrade of all positions within its CDS portfolio of mortgage backed CDOs would trigger an immediate increase in its aggregate derivative liability of $\$ 335$ million. ${ }^{128}$

In light of this basic relationship between Ambac's earnings and the credit ratings of its CDOs, it was hardly surprising that the significant downgrades in its CDO portfolio during 2008 were routinely followed by the announcement of significant quarterly losses arising from CDO valuation adjustments. For instance, when announcing its record quarterly loss of $\$ 1.6$ billion on April 23, 2008, Ambac noted the importance of "a net mark-to-market loss amounting to $(\$ 1,725.2)$ million ... related to contracts executed in credit default format, primarily in our collateralized debt obligation exposures." 129 Moreover, it further emphasized that

[p]ricing declines [of the CDOs] were observed throughout the quarter but were exceptionally large in March as recent poor transactional performance became public. Prices continue to be driven down by poor collateral performance, rating agency downgrades and uncertainty regarding the ultimate outcome of subprime and other residential mortgage-backed securities losses. ${ }^{130}$

Of course, all of this is consistent with Table 3, which shows that over $\$ 5$ billion of its insured CDOs were downgraded from AAA to below investment grade in the first quarter of 2008 with $\$ 3$ billion being downgraded in March alone. ${ }^{131}$ Yet in contrast to the absence of any significant market reaction upon each downgrade date, Ambac's stock experienced a significant, one-day abnormal return of negative $43 \%(z=-3.46)$ on April 23 , the day of the earnings announcement. ${ }^{132}$

equity during March 2008, its 2008 losses would have entirely depleted its available statutory capital. See id. (reflecting a deduction of Ambac's $\$ 4.4$ billion net loss from its statutory surplus as well as a capital contribution of $\$ 2$ billion).

125. Ambac 2007 10-K Report, supra note 9, at 53-54.

126. Id.

127. Id.

128. Id.

129. Press Release, Ambac Financial Group, Inc., Announces First Quarter Net Loss of $\$ 1,660.3$ Million (Apr. 23, 2008), available at http://www.ambac.com/Press/042308.html.

130. Id.

131. See supra Table 3.

132. This one-day abnormal retum was calculated using the single-factor market model described 
Indeed, the stark contrast between the significant market reaction following this earnings announcement and the weak reaction following the CDO downgrades that precipitated it provides perhaps the strongest evidence to question the efficiency with which the stock market was processing Ambac's CDO disclosures. As noted above, Ambac's annual report had portrayed a fairly direct relationship between CDO rating downgrades and Ambac's earnings, making the insurer's significant quarterly loss a seemingly predictable consequence of the massive downgrades listed in Table 3 . To be sure, the market's negative reaction to Ambac's April 23 announcement undoubtedly included both a reaction to Ambac's first quarter loss as well as the market's anticipation of further bad news in the future. Even so, the question remains why investors would manifest this reaction on April 23 rather than on the downgrade dates set forth in Table 3. Whether Ambac's first quarter loss signaled past or future CDO write-downs, these significant downgrades should have been dependable harbingers of the earnings announcement on April 23. ${ }^{133}$

In summary, if Ambac's investors were using the company's portfolio-level disclosures to reduce their uncertainty about its derivatives liability, they did so in a much less direct fashion than in the case of PG\&E. Indeed, compared with the PG\&E experience, the general absence of any notable market reaction to these significant CDO downgrades would seem to call into question whether these disclosures mattered at all.

\section{CDO DOWNGRADES AND ARBITRAGE ACTIVITY}

In theory, one possible explanation for the lack of any significant market reactions to the ratings downgrades set forth in Table 3 could relate to the efficiency with which investors were anticipating these downgrades based on fundamental analysis of the insured CDO securities. As discussed previously, the CDO market during 2008 was considerably more transparent than has traditionally been assumed, and for most CDOs Ambac insured, an entrepreneurial investor could obtain a large amount of both legal and financial data regarding an insured CDO by simply logging onto the Internet. In particular, offering prospectuses for all six CDOs analyzed in Part III.C were available online through the Irish Stock Exchange's website, ${ }^{134}$ while monthly financial reports, portfolio schedules, and other financial information were available on the CDO trustees' websites. ${ }^{135}$ Although the information would not be as comprehensive as in the case of

previously, using April 23, 2008 as the relevant event date.

133. Notably, this conclusion would appear to apply even if the market had come to doubt the accuracy of credit ratings by early 2008 . In the case of structured finance vehicles, rating agencies generally update their ratings based on the monthly remittance reports submitted to investors by the issuer's collateral manager. See, e.g., Uzair Aftab, S\&P Takes Rating Actions on 8 Subprime RMBS Deals, SNL BANK WEEKLY S. EDITION, Aug. 4, 2008 (reporting that S\&P downgrades of certain RMBS transactions were based on principal writedowns reported in the issuers' May and June remittance reports). As a result, even where investors might doubt the accuracy of a rating assigned to a particular issue, a sudden and significant downgrade of the type set forth in Table 3 would nonetheless signal the receipt by the CRA of exceptionally poor remittance reports, as was the case in the spring of 2008 for many CDOs. Indeed, for those investors who had come to doubt the integrity of CRAs, a significant downgrade of a CDO might signal the receipt of a remittance report that was so poor as to force even a conflicted CRA to come clean in its ratings.

134. See supra note 37 and accompanying text (discussing publication requirements of the Prospectus Directive).

135. See supra note 41 (discussing trustee disclosures). 
notes that are registered under the Securities Act, it would nonetheless provide a significant amount of data pertaining to the collateral underlying a $\mathrm{CDO}$, the legal rights associated with individual tranches of securities, and the monthly cash flows to and from the CDO. Accordingly, the absence of abnormal returns following a ratings downgrade might simply reflect the fact that investors were efficiently processing these lower-tier disclosures to anticipate the rating actions.

Before proceeding further, however, it is important to note that whatever conceptual appeal this explanation provides is diminished by the fact that it would seem to apply with even greater force to the downgrade of PG\&E. Indeed, because PG\&E was a periodic reporting company under the Exchange Act, the legal and financial information needed to predict a downgrade of PG\&E was both more comprehensive and easier to obtain than in the case of the CDOs listed in Table 3. Among other things, PG\&E's public disclosures provided quarterly and annual financial statements that were GAAPcompliant as well as certain mandatory periodic updates-items that were generally absent in the case of CDO disclosures. ${ }^{136}$ PG\&E's disclosures were also made through the SEC's Edgar reporting system, which provides a centralized and searchable electronic repository for all mandatory SEC filings. CDO disclosures, in contrast, would have to be collected by resorting to a variety of different repositories of public information. Notwithstanding the greater ease with which an investor could build a model of PG\&E's default probability, PG\&E's first two downgrades were nonetheless associated with significant negative abnormal returns for Ambac. Moreover, even if Ambac's investors could engage in perfect prediction of ratings downgrades, it would still leave unresolved why its stock price declined so significantly when Ambac announced the consequence of these downgrades upon releasing its quarterly earnings in the spring of 2008. ${ }^{137}$

Absent a compelling reason to believe investors were accurately predicting CDO ratings downgrades, the evidence presented in Part III thus continues to raise the question: where were sophisticated investors during the ratings downgrades? Indeed, the absence of a significant market reaction to the downgrades in Table 3 is all the more puzzling given the opportunity for significant arbitrage profits they provided. For instance, shorting a single share of Ambac common stock on each of the first four downgrade dates analyzed in Part III would have yielded a raw return of $66.32 \%$ on April

136. Specifically, PG\&E's status as a listed company on the New York Stock Exchange subjected it to the periodic reporting requirements of the Securities Exchange Act of 1934. 15 U.S.C. $\S$ 781.(b) (2006). In contrast, while the Prospectus Directive might require a CDO to file publicly its offering prospectus, see supra notes 30 37, CDOs of the type insured by Ambac were not generally subject to any mandatory periodic reporting requirements. See, e.g., RIDGEWAY COURT FundiNG II, LTD AND RIDGEWAY COURT FUNDING II, CORP. OFFERING CIRCULAR 55 (Aug. 28, 2007), available at http:/www.ise.ie/debt_documents/RIDGEWAY 28.08.07_9274.pdf (describing the absence at the time of its offering of any periodic reporting obligations under European Union law). In 2007, the European Union implemented the Transparency Directive which requires issuers having securities listed for trading on European exchanges to file annual and half-yearly financial reports-including financial accounts audited in accordance with International Financial Reporting Standards-but its implementation in Ireland resulted in a delay of approximately one year before issuers were required to publish their first reports. See Memorandum from Daryl Byrne \& Gerald Scully to All Listing Agents (June 18, 2007), available at http://www.ise.ie/index.asp?locID=525\&docID=-1 (describing the implementation of the Transparency Directive in Ireland).

137. See supra note 132 and accompanying text (discussing Ambac's negative abnormal return following its earnings announcement on April 23, 2008). 
23,2008 , the day Ambac announced the quarterly loss produced by these downgrades. ${ }^{138}$ Unless large numbers of investors were assuming the market was perfectly predicting the ratings downgrades, the direct relation between Ambac's earnings and the ratings of its CDOs should have motivated at least some investors to trade on any new information concerning the credit quality of Ambac's CDO positions. As Stanford Grossman and Joseph Stiglitz famously noted, it is precisely where information is costly to obtain and process, such as predicting a CDO's credit riskiness, that investors have their strongest incentives to search for and trade on new information. ${ }^{139}$

The following three subparts examine the role of more sophisticated investors in processing Ambac's derivative disclosures by considering three sources of information: aggregate levels of short selling activity in Ambac common stock, changes in the daily pricing of credit default swaps written on Ambac's senior debt securities, and a case study of a prominent hedge fund's short position in Ambac that it took during the winter of 2008.

\section{A. Short Selling Activity in Ambac's Common Stock}

One possible explanation for the absence of any significant stock price reactions in Part III.C is that the rising volatility in Ambac's stock concealed the downward price pressure created by sophisticated investors who were selling or shorting Ambac's stock. Under ordinary trading conditions, if investors sell (or short sell) large amounts of a company's stock, a significant negative abnormal return should appear given the downward price pressure the sales create. By early 2008, however, market conditions were hardly ordinary. As noted in Part III, Ambac's stock had become increasingly volatile in late 2007 and early 2008 as the U.S. housing market continued to deteriorate. ${ }^{140}$ Daily trading volume similarly increased from an average of approximately 3.5 million shares in 2007 to almost 15 million shares during the first three months of $2008 .{ }^{141}$ These developments suggest the presence of a significant amount of "noise trading"- that is, trading by investors who have hedging motives or who might be cognitively biased-which, under some theoretical models, can overwhelm the pricing effects of rational arbitrageurs. ${ }^{142}$

138. Based on this simple strategy, short sales would have occurred on January 17, February 20, March 14, and March 24, with the transaction closing out on April 23, 2008. For purposes of this illustration, the hypothetical strategy was made in accordance with the margin requirements set forth in Regulation $\mathrm{T}$, see infra note 210 , and ignores commission and brokerage fees. The four transactions would have required a total cash outlay of $\$ 15.40$, consisting of four margin deposits on the day of each short sale and one margin call of $\$ .99$ on January 23,2008 . The strategy also accounts for a $\$ 0.07$ dividend per share paid on February 7,2008 . The speed with which the $66.32 \%$ raw retum was produced translates to an internal rate of retum of $1834 \%$.

139. See Sanford J. Grossman \& Joseph E. Stiglitz, On the Impossibility of Informationally Efficient Markets, 70 AM. ECON. REV. 393 (1980) (proposing a model with an equilibrium degree of disequilibrium, where those who expend resources to gain information are compensated). The insight is frequently referred to as the Grossman-Stiglitz paradox.

140. See supra notes 99-100 and accompanying text (discussing Ambac's negative earnings announcements in 2007 and 2008).

141. These figures were obtained from the Center for Research in Securities Prices.

142. While the direct effect of adding noise traders to a securities market reduces informational efficiency, it also produces countervailing effects that might theoretically permit markets to remain efficient. Consistent with the Grossman-Stiglitz paradox, greater noise trading in a securities market can motivate arbitrageurs to 
To examine more precisely the extent to which sophisticated arbitrageurs might have been processing Ambac's derivative disclosures, I turned to the bi-monthly reports of short positions in Ambac common stock as collected by the Financial Industry Regulatory Authority (FINRA). Beginning in September 2007, FINRA required that all securities firms subject to its oversight report on a bi-monthly basis the total short positions in all customer and proprietary firm accounts in any over-the-counter and exchange-listed securities to enable FINRA and market participants to understand the level of short selling activity in U.S. equity markets. ${ }^{143}$ In general, the FINRA rule requires all broker-dealers to report open short interests in their customer and proprietary accounts on a security-by-security basis as of both mid-month (approximately the fifteenth of each month) and month-end (generally the last day of the month). While short interest levels in the interim days remain beyond the scope of the rule, these bi-monthly, security-by-security reports-which are aggregated by FINRA and released to the public-provide a snapshot of the total amount of outstanding short interest in individual stocks as of these two reporting days. Using these data, Figure 1 provides the short interest for Ambac from September 2007 through the end of 2008.

trade with noise traders, thereby enabling arbitrageurs to capture profits from their investment in research. See Ronald J. Gilson \& Reinier Kraakman, The Mechanisms of Market Efficiency Twenty Years Later: The Hindsight Bias, 28 J. CORP. L. 715, 733 (2003) ("As the volume of irrational trades increases, a point is reached where the arbitrageur's most profitable strategy shifts from betting against the noise traders to buying in front of them, with the goal of exploiting the noise traders mistake by selling them overvalued stock."). Accordingly, Grossman and Stiglitz and Albert Kyle both provide models showing how an increase in noise trading will not harm informational efficiency. See Grossman and Stiglitz, supra note 139 (providing models demonstrating noise trading's effects); Albert S. Kyle, Continuous Auctions and Insider Trading, 53 ECONOMETRICA 1315 (1985) (examining the value of information to insider trading). Other models, however, note that various limits to arbitrage might prevent this outcome from occurring. See, e.g., Bradford J. DeLong, et al., Noise Trader Risk in Financial Markets, 98 J. POL. ECON. 703 (1990) (presenting a model where irrational noise traders affect prices and deter rational arbitrageurs from aggressively betting).

143. See NATIONAL AsSociation OF SECURITIES DEALERS, NTM 07-24, Notice to MEMBERs (May 2007) (requiring members to increase the frequency of short interest reporting to twice a month). All bi-monthly shortselling data was obtained from Compustat. 
Figure 1: Bi-Monthly Short Positions in Ambac Financial, 2007-08

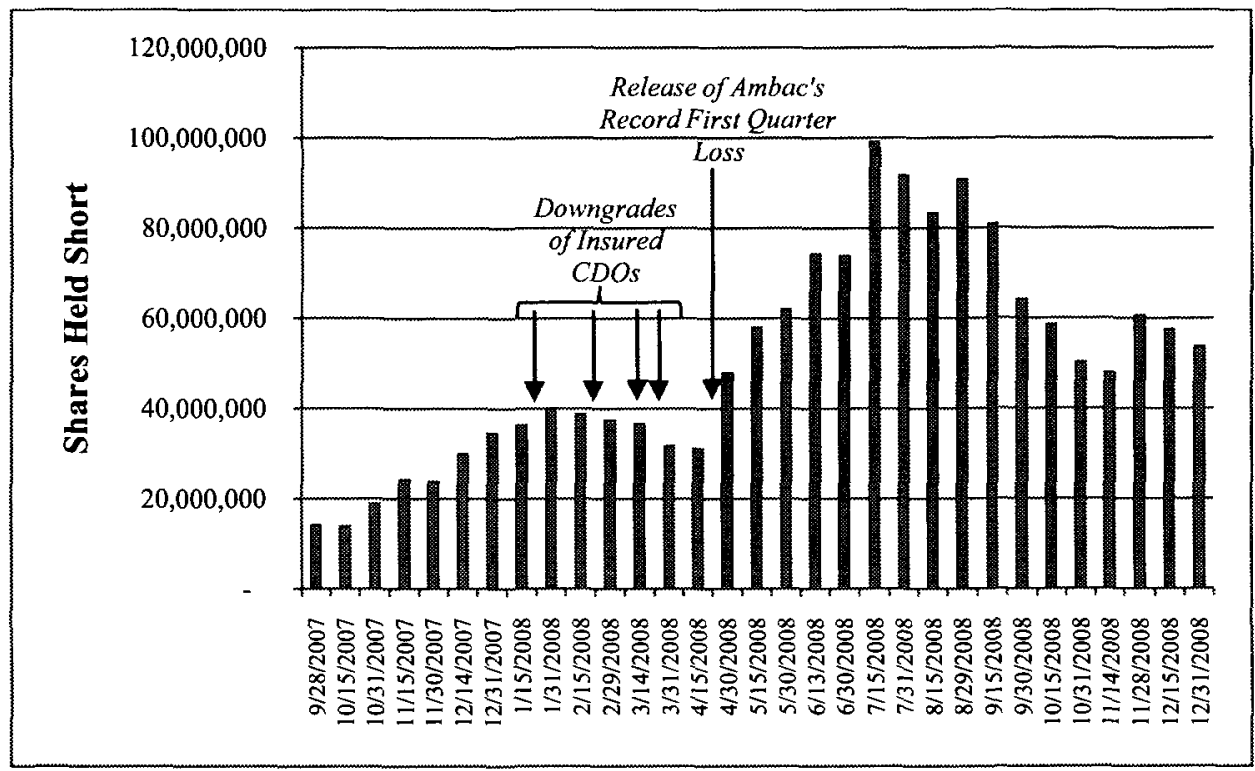

Not surprisingly, Figure 1 reveals a sharp increase in short selling activity from October 2007 through most of 2008, reaching a peak in July 2008. Examining whether the six downgrades analyzed in Part III affected short selling activity, however, is made difficult by the fixed reporting dates used by FINRA. For instance, most of the downgrades analyzed in Part III were announced several days before the mid-month or month-end reporting dates, thus impairing a direct analysis of how short interest levels might have changed in response to an announced downgrade. Nonetheless, it is notable that short selling interests during the first quarter of 2008 (although generally higher than the fourth quarter of 2007) decreased from 40 million shares as of January 31, 2008 to 32 million shares as of March 31,2008. Given that four of the six downgrades analyzed in Part III occurred during these reporting periods, this overall trend hardly seems to support the notion that sophisticated short sellers were closely monitoring the individual downgrades of Ambac's largest CDO positions.

The downgrade of Kleros Preferred Funding VI (Kleros VI) on March 14, 2008 is particularly notable in this regard. Ambac had insured \$2.4 billion of the senior-most tranche of Kleros VI, making the position one of Ambac's largest CDO exposures. ${ }^{144}$ The March 14 downgrade also represented one of the most significant that Ambac would experience in its CDO portfolio, with the insured notes being downgraded a full 16 notches from AAA to CCC+ in a single day. Yet the short interest report measured as of

144. See Ambac 2009 10-K REPORT, supra note 26, at 8 (2010) (listing Kleros VI exposure). Based on the Kleros VI prospectus, Ambac wrapped $\$ 1$ billion of Class A-1S-1A First Priority Senior Secured Notes and $\$ 1.4$ billion of Class A-1S-1B First Priority Senior Secured Notes. See KLEROS PREFERRED FUNDING VI, LTD. KLeRos Preferred Funding VI, LlC, OfFering CirCulaR 1 (June 6, 2007) [hereinafter Kleros VI Prospectus], available at http://www.ise.ie/debt_documents/kleros_5756.pdf. 
the close of that same day indicates a slight decrease in short selling interest from the end of February. The short interest report for March 31 reveals a further decline in outstanding short interest levels.

In contrast, while short selling levels did not change after these announced downgrades, Ambac's April 23 announcement of the consequence of these downgrades on its first quarter earnings triggered a significant surge in short selling. Just as the April 23 announcement produced a significant one day abnormal return of negative $43 \%$ in Ambac's stock price, ${ }^{145}$ the first short interest report following the announcement revealed a $54 \%$ increase over the prior report. Indeed, the increase was so significant that the Wall Street Journal reported it as the second largest percentage increase among all NYSE-listed firms for the April 30 reporting date. ${ }^{146}$ Thus, rather than anticipating Ambac's April 23 earnings announcement based on downgrades to its $\mathrm{CDO}$ portfolio, short sellers appeared to have been just as surprised by Ambac's first quarter earnings as the market as a whole.

\section{B. Changes in the Price of Insuring Ambac's Senior Indebtedness}

The conclusion that even sophisticated investors might have been ineffective in processing downgrade announcements affecting Ambac's CDO positions is further supported by analysis of the credit default swap (CDS) market. In addition to shorting Ambac's common stock, investors who sought to profit from Ambac's deteriorating financial condition in 2008 could have also turned to an increasingly liquid market in single-name credit default swaps.

As noted previously, a CDS contract generally replicates the financial structure of a traditional bond insurance contract insofar that the seller of the CDS must pay the CDS purchaser a specific notional value (e.g., the face value of the bond) upon an issuer experiencing certain specified credit events (e.g., the bond issuer's bankruptcy or a default in the payment of principal or interest). ${ }^{147}$ In exchange, the protection buyer pays periodic premium payments to the protection seller, with the premiums being fixed at the time of the CDS contract based on the bond issuer's then-existing credit risk. An investor who sought to "go short" Ambac's credit might therefore purchase a five-year CDS on Ambac's outstanding bonds with a $\$ 10$ million notional amount, which would pay $\$ 10$ million upon Ambac's incurrence of a specified credit event. Moreover, because the premium payment would be fixed at the inception of the CDS contract, any increase in the probability of an Ambac credit event and a concomitant payout on it would produce an increase in the value of the CDS contract, which the investor could monetize through various trading strategies. ${ }^{148}$

145. See supra note 132 and accompanying text (discussing Ambac's negative abnormal return following its earnings announcement on April 23, 2008).

146. Factbox: Biggest Changes in NYSE Short Interest, WALL ST. J., May 6, 2008.

147. While in theory a protection buyer could negotiate a CDS that obligated the protection seller to pay any notional amount upon a specified credit event (e.g., the bankruptcy of Ambac), most dealers of CDS sell CDS contracts in increments of between $\$ 10$ million and $\$ 20$ million in notional amount. NOMURA FIXED INCOME RESEARCH, CRedit Default SWAP (CDS) PRIMER (May 12, 2004), available at http://www.securitization.net/pdf/content/Nomura_CDS_Primer_12May04.pdf.

148. In general, monetizing this gain generally requires the protection buyer to enter into an off-setting CDS. Assume, for example, that an investor purchases $\$ 10$ million worth of CDS protection on Ambac for two 
As with short-selling then, analyzing the pricing of Ambac's CDS contracts provides a useful way to examine the extent to which sophisticated investors were analyzing the credit condition of Ambac's CDO portfolio. In particular, if dealers and investors anticipated an increase in the default risk of Ambac due to its deteriorating CDO portfolio, prices for CDS protection on Ambac debt should reflect an increase as well given that sellers of credit protection will demand a higher premium as compensation for the incremental increase in Ambac's default risk. At the same time, because the CDS market is generally dominated by institutional investors, it should also be less prone to the potentially confounding effect of noise trading than in the case of equity trading. For instance, even with short-selling Ambac's common stock, arbitrageurs might be influenced by both their assessment of Ambac's financial condition as well as their anticipation of how noise traders will react (or overreact) to salient news events, such as Ambac's announcement of its record quarterly loss in April 2008. ${ }^{149}$ To the extent that the CDS market is dominated by sophisticated investors, these ancillary effects on asset pricing should be more muted, making CDS pricing a potentially purer reflection of how sophisticated investors were processing publicly available information concerning Ambac's credit worthiness.

For purposes of conducting the CDS analysis, prices for Ambac's CDS were obtained from the Credit Market Analysis (CMA) data provided through Bloomberg. Because there was no central clearinghouse or exchange for trading CDS in 2008, CMA's pricing data were collected from financial institutions (such as asset managers, hedge funds, and banks) who provided CMA with prices of executed trades and recent bids on specific debt instruments ranging in both tenor and seniority. ${ }^{150}$ While the absence of a central exchange for CDS undoubtedly introduced some inefficiencies into the pricing of swaps, the data provided by CMA nevertheless provide a direct window into how some of the most sophisticated investors in the capital markets were assessing Ambac's credit risk during 2008.

As in Part III, for each of the six downgrade dates, I examined the one-day and twoday price changes in the five-year CDS for Ambac. ${ }^{151}$ The results are set forth in Table 4. ${ }^{152}$ With respect to both one-day and two-day returns, January 17, 2008 and November 5, 2008 each witnessed meaningful increases in the price charged for a five-year CDS for Ambac, with CDS prices in each case jumping approximately $60 \%$ over two-days. As

years at a cost of 500 basis points $(5 \%)$ per year. Assume further that after one year Ambac's default risk increases, raising the cost of purchasing protection on Ambac to 1500 basis points. By selling $\$ 10$ million of protection on Ambac for one year at this higher rate, the investor would capture the gain on the increased spread. In particular, after the full two years and assuming no default by Ambac, the investor will have paid $\$ 1$ million in premium payments $(\$ 500,000$ per year), but it would have received $\$ 1.5$ million in premium payments from its off-setting CDS contract, thereby producing a net profit of $\$ 500,000$.

149. See supra note 142 and accompanying text (discussing effect of noise trading on market efficiency).

150. See Intraday \& End-of-Day CDS Prices, CREDIT MARKET ANALYSIS, LTD., http://www.cmavision.com/products-solutions/intraday-and-end-of-day-cds-prices (last visited October 3, 2010) (describing CMA's services).

151. More precisely, the pricing data reflect the CDS spreads for contracts written on the senior debt of Ambac Assurance Corp., the operating subsidiary that conducted all of Ambac's financial guarantee business. See Ambac 2007 10-K Report, supra note 9, at 2 ("Ambac provides financial guarantee insurance for public and structured finance obligations through its principal operating subsidiary, Ambac Assurance Corporation.").

152. See infra Table 4. 
noted in Part III however, news regarding Ambac on each of these dates was dominated largely by Moody's decision to place Ambac on review for downgrade-announced on January 17-and Ambac's release of its third quarter loss-announced on November 5. ${ }^{153}$ As a result, these substantial price increases most likely reflect investors' responses to these negative announcements.

Table 4: Raw Price Changes in 5-year Credit Default Swaps Written on Ambac Assurance Corp. ${ }^{154}$

\begin{tabular}{|c|c|c|c|c|c|c|}
\hline Event Date: & $1 / 17 / 2008$ & $2 / 20 / 2008$ & $3 / 14 / 2008$ & $3 / 24 / 2008$ & $11 / 5 / 2008$ & $12 / 1 / 2008$ \\
\hline CDO Downgraded: & $\begin{array}{c}\text { Adams } \\
\text { Square } \\
\text { Funding II }\end{array}$ & $\begin{array}{l}\text { Ridgeway } \\
\text { Court } \\
\text { Funding II }\end{array}$ & $\begin{array}{l}\text { Kleros } \\
\text { Preferred } \\
\text { Funding } \\
\text { VI }\end{array}$ & $\begin{array}{l}\text { Caim } \\
\text { High } \\
\text { Grade } \\
\text { ABS } \\
\text { CDO II }\end{array}$ & $\begin{array}{c}\text { Duke } \\
\text { Funding } \\
\text { High } \\
\text { Grade III }\end{array}$ & $\begin{array}{c}\text { Tremonia } \\
\text { CDO } \\
2005-1\end{array}$ \\
\hline $\begin{array}{l}\text { Insured Amount } \\
\text { (millions): }\end{array}$ & $\$ 600$ & $\$ 1,950$ & $\$ 2,400$ & $\$ 819$ & $\$ 1,750$ & $\$ 825$ \\
\hline $\begin{array}{l}\text { Agency Making } \\
\text { Downgrade: }\end{array}$ & Moody's & S\&P & S\&P & Moody's & Moody's & Moody's \\
\hline Downgrade in Notches: & 11 & 11 & 16 & 11 & 10 & 12 \\
\hline Resulting Credit Rating: & $\mathrm{Ba} 2$ & BB & $\mathrm{CCC}+$ & $\mathrm{Ba} 2$ & Bal & $\mathrm{Ba} 3$ \\
\hline $\begin{array}{c}\text { One-day change in CDS } \\
\text { price: }\end{array}$ & $64.80 \%$ & $-3.60 \%$ & $6.60 \%$ & $-2.70 \%$ & $13.90 \%$ & $2.40 \%$ \\
\hline $\begin{array}{l}\text { Cumulative two-day } \\
\text { change in CDS price } \\
\qquad(0,+1)\end{array}$ & $62.10 \%$ & $0.50 \%$ & $9.70 \%$ & $-9.10 \%$ & $65.40 \%$ & $0.50 \%$ \\
\hline
\end{tabular}

Of the remaining four dates, the only meaningful price increase occurred on March 14. On that day, the cost of insuring Ambac's debt increased 6.6\%, which would increase another $3.1 \%$ the following day. To assess the statistical significance of this increase, Figures $2 \mathrm{a}$ and $2 \mathrm{~b}$ provide histograms of the one- and two-day price changes for Ambac's five-year CDS during all of $2008 .{ }^{155}$ As the figures indicate, one-day and two-day price changes in 2008 were non-normal in their distributions, making standard statistical inference inappropriate. In particular, assuming one-day price changes followed a normal distribution would suggest that any price change of less than $19.4 \%$ had at least a $5 \%$ chance of being the product of random variation in Ambac's CDS prices that year. In

153. See supra notes 106-07 and accompanying text (discussing the effect of these events on Ambac's equity returns).

154. This table reports the one- and two-day percentage changes in CDS prices of Ambac Assurance Corp. following the announcement of a major ratings downgrade in 2008 of six CDO exposures insured by Ambac. For this purpose, a major downgrade is defined as involving a rating downgrade of at least ten notches. All CDS prices were taken from Bloomberg and reflect the annual premium (in basis points) of insuring for five years the senior debt of Ambac Assurance. The statistical significance of these pricing changes is discussed in the text.

155. See infra Figures $2 a$ and $2 b$. 
contrast, using the distribution of one-day price changes as a rough estimate of the probability density function for Ambac's CDS prices would suggest a critical value closer to $15.5 \%$. Even so, the one-day price increase of $6.6 \%$ on March 14 would be well below it. With respect to the two-day price increase of $9.7 \%$ following March 14, Figure $2 \mathrm{~b}$ also indicates that two-day price changes in 2008 suggest a critical value closer to $22.5 \%$ more than twice the two-day price change that occurred on that date.

Figure 2a: Distribution of Single Day CDS Prices Changes for Ambac in $2008 \mathrm{v}$. Normal Distribution

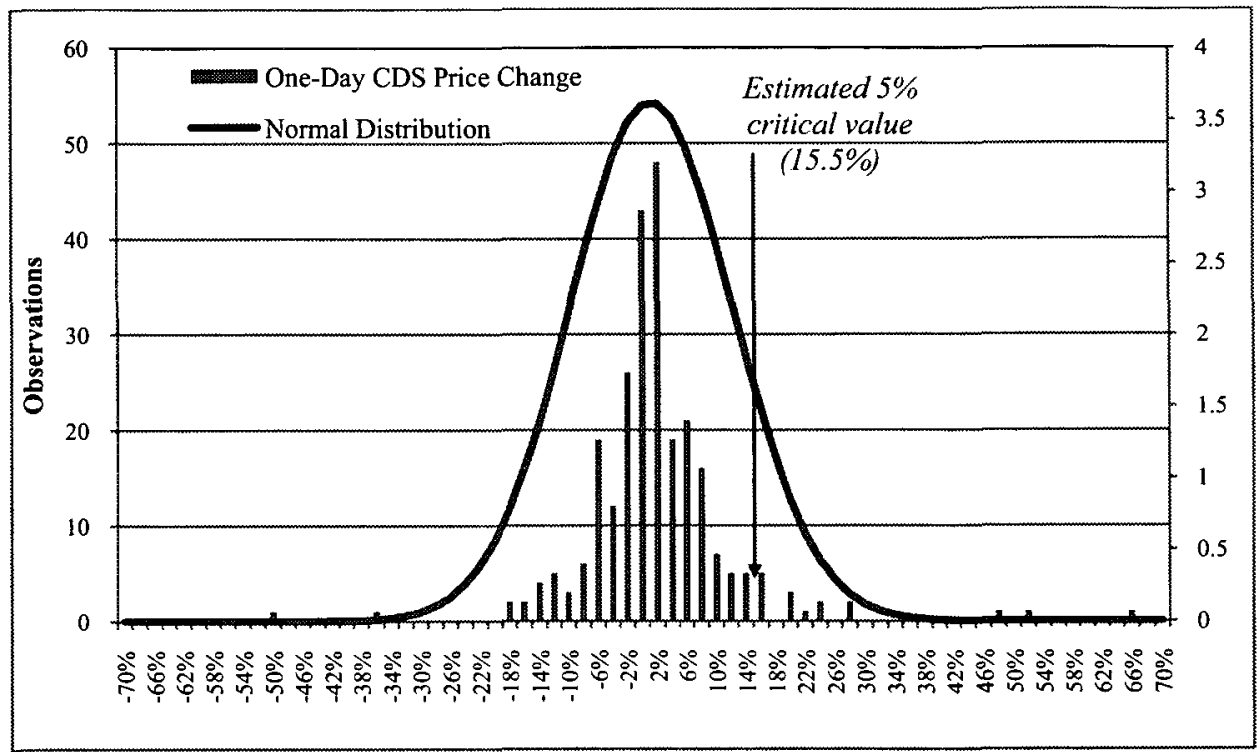


Figure 2b: Distribution of Two-Day CDS Price Changes for Ambac in 2008 vs. Normal Distribution

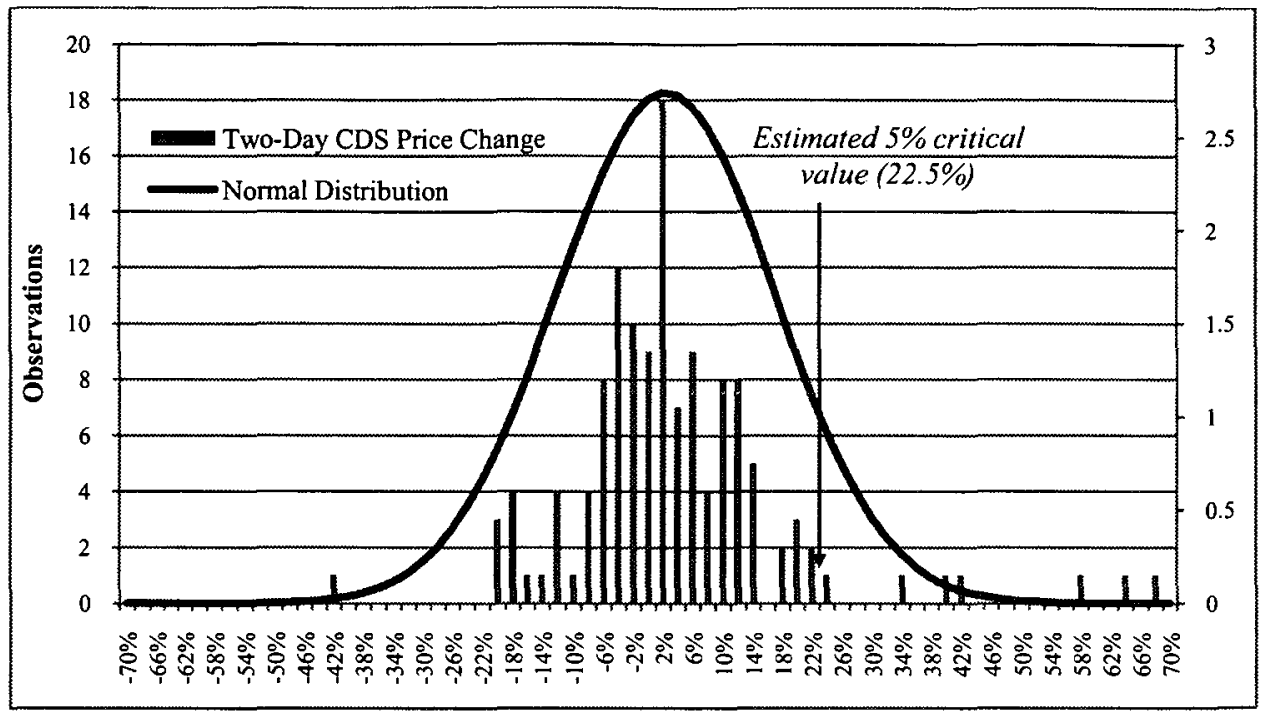

Moreover, as with both the event study analysis and the short-selling data, CDS investors appeared to have responded much more directly to the consequence of these downgrades on Ambac's earnings. Following Ambac's announcement of its record loss on April 23, 2008, the price of insuring Ambac debt jumped $13 \%$ that day. While this one-day price increase was slightly below the one-day critical value noted above, spreads for Ambac five-year CDS rose another $11.4 \%$ on April 24. This subsequent increase would take the two-day price increase to $24 \%$, just within the top $5 \%$ of two-day price increases in 2008. Thus, in combination with the short interest analysis in Part IV.A, Ambac's CDS pricing suggests that even sophisticated institutional investors may have been ineffective in processing the announcement of significant downgrades within Ambac's structured finance portfolio.

\section{Case Study of Pershing Square Capital}

Given the potential to profit on the aforementioned downgrades in both the equity and CDS markets, the lack of any significant response in these markets to the downgrade announcements is puzzling to say the least. This is especially true in the case of the shortselling results, given that professionally informed arbitrage has long been believed to be a key mechanism driving public equity markets towards informational efficiency. In their seminal article on the mechanisms of market efficiency, Ron Gilson and Reiner Kraakman summarized the intuition as follows:

How, then, do prices come to reflect this semi-public information? The answer, as identified in general terms by [Eugene] Fama and many others, is that rapid price equilibration does not require widespread dissemination of information, but only a minority of knowledgeable traders who control a critical volume of trading activity .... [T] he professionally informed trading mechanism explains 
why any information that is accessible to significant portions of the analyst community is properly called 'public,' even though it manifestly is not. Such information is rapidly assimilated into price, with only minimal abnormal returns to its professional recipients. And it is these characteristics, we submit, that largely convey the meaning of a 'semi-strong form' market response. ${ }^{156}$

To be sure, Gilson and Kraakman acknowledged that a number of real world considerations can limit the ability of arbitrageurs to function in this way, and a large literature in finance has explored how these real-world limits on arbitrage can produce persistent mispricings in otherwise efficient markets. ${ }^{157}$ Yet many of the most important limitations on arbitrage would appear to be of little consequence when it came to profiting on the six downgrades examined in Part III. Indeed, one of the most discussed limits on arbitrage-the uptick rule-was repealed by the Securities and Exchange Commission from 2007 to 2009 , thus freeing short sellers from its constraints at the time of the downgrades. ${ }^{158}$ Similarly, Ambac's limited number of outstanding shares of common stock, although potentially an important constraint on short-selling, was unlikely to affect arbitrageurs in the spring of 2008. As noted earlier, Ambac completed a public offering of approximately 115 billion shares of common stock in early March 2008, thereby dramatically increasing the supply of shares for short-sellers to borrow (particularly with respect to the downgrade of Kleros VI). More generally, the possibility that institutional limits on short-selling explain the absence of trading activity on the six downgrade dates seems inconsistent with the significant short-selling in Ambac common stock that occurred following Ambac's first quarter earnings report. ${ }^{159}$

But if not traditional arbitrage limitations, what might explain why even sophisticated investors did not appear to process the six downgrades in Ambac's CDO portfolio? The fact that private, individual investors often use proprietary techniques to analyze public disclosures generally makes it difficult to examine the black box that investors use to process information. In the case of Ambac's CDO disclosures, however, this challenge is mitigated due to a public relations battle that was waged in the winter of 2008 between Ambac and Pershing Square Capital (Pershing Square), a hedge fund that had accumulated a large short position in the company.

Since 2002, Pershing Square's founder, William Ackman, had been the monoline industry's most vocal skeptic, publishing a number of reports questioning the insurers' high credit ratings and periodically shorting the companies' stock. ${ }^{160}$ By May 2007,

156. Gilson \& Kraakman, supra note 45 , at 570-72.

157. See generally Nicholas Barberis \& Richard Thaler, A Survey of Behavioral Finance, in HANDBOOK OF THE ECONOMICS OF FINANCE 1054-62 (George Constantinides et al. eds., 2003) (summarizing research).

158. From 1938 until 2007, the so-called "uptick" rule was implemented through SEC Rule 10a-1, 72 Fed. Reg. 36, 348-59 (2007), which permitted the selling of borrowed shares only after an increase (or uptick) in the share price. Its repeal in 2008 therefore permitted short-selling to occur in Ambac stock without any need for traders to ensure that their short sales were made at specified prices.

159. See supra Part IV.A. (discussing short-selling activity in Ambac's common stock in 2007 and 2008).

160. See, e.g., Aaron Smith, Gotham Partners Report Finds Fault with MBIA's Triple-A, BOND BUYER, Dec. 11, 2002 (discussing Ackman's first assault on the monoline industry in 2002 when he published a sixtysix page analysis questioning MBIA's financial position). Following the revelation that Ackman had entered into a short position in MBIA's stock prior to publicizing the report, Eliot Spitzer investigated his hedge fund for possible market manipulation. Bethany McLean, The Mystery of the \$890 Billion Insurer, FoRTUNE, May 16, 2005, available at http://money.cnn.com/magazines/fortune/fortune_archive/2005/05/16/8260164/ 
Ackman had again taken a significant short position in MBIA and Ambac and had begun an active public relations campaign to publicize their exposure to the subprime mortgage industry that was quickly deteriorating. ${ }^{161}$ Not satisfied with his traditional tactics, on January 31, 2008, Ackman sent to the Securities and Exchange Commission, the New York Superintendent of Insurance, and a number of national newspapers an elaborate financial model providing extensive details on each CDO insured by Ambac and MBIA, the insurers' exposures to them, as well as their probable losses. Dubbing it the "Open Source Model," Ackman expected the customizable model would "enable market participants and regulators to accurately estimate probable losses by relying on rigorous fundamental analysis of specific credit exposures . . .."162

Given the skepticism about the ability of investors to analyze complex securitization transactions in real-time, the Open Source Model was remarkable in its ambition. Although MBIA and Ambac had insured only 28 and 30 exposures, respectively, each of these held between 50 and 200 securities, each of which were either conventional mortgage-backed securities ${ }^{163}$ - which might consist of hundreds of home mortgagesor other CDOs-which Pershing referred to as "inner-CDOs". ${ }^{164}$ Estimating losses on the 58 "outer CDOs" insured by Ambac and MBIA required Pershing Square to identify the CUSIP number ${ }^{165}$ of each mortgage-backed security (MBS) held within the CDOs that Ambac and MBIA insured, as well as the CUSIP numbers of any inner-CDOs. Next, identification of all MBS held within any inner-CDO (and within any inner-inner-CDOs) needed to be completed until Pershing Square had identified the full universe of MBS on which the performance of the inner-CDOs and outer CDOs depended. Ultimately, the model revealed that the CDO portfolio of each insurer was exposed to over 3000 unique tranches of MBS and over 400 CDOs. ${ }^{166}$

index.htm. No charges were filed, but the investigation initially harmed Ackman's credibility regarding his dire assessment of the monoline industry and eventually contributed to the liquidation of Ackman's initial hedge fund, Gotham Partners. Id. In 2004, however, Ackman's credibility resurged following MBIA's restatement of its earnings, due in part to a transaction that he had questioned. See id. (discussing Ackman's criticisms of MBIA's business). Ackman formed Pershing Square in November 2003. Josh Fineman, McDonald's Stake Purchased by Pershing, Person Says, BloOMBerg.COM, Sept. 16, 2005, http://www.bloomberg.com/apps/ news?pid=email_us\&refer=top_world_news\&sid=aYHMVNhrr.hM (last visited October 8, 2010).

161. See Alistair Barr, Pershing's Ackman Knocks MBIA, Ambac Bond Guarantors Exposed to Subprime Fallout, Hedge Fund Manager Says, MARKETWATCH, May 24, 2007, http://www.marketwatch.com/story/ hedge-fund-manager-says-mbia-ambac-exposed-to-subprime-fallout (discussing Ackman's report on MBIA's and Ambac's exposure to subprime mortgages).

162. Letter from William A. Ackman to The Honorable Eric E. Dinallo, Superintendent of Insurance, State of New York 2, Jan. 30, 2008, available at http:/graphics8.nytimes.com/packages/pdf/business/20080131 opensourceletter.pdf [hereinafter Ackman Letter].

163. These figures, as well as the analysis that follows, are based on a review of the Open Source Model provided by Pershing Square.

164. See Ackman Letter, supra note 162 (defining "inner-CDOs" as those CDO exposures held by CDOs that were directly insured by Ambac or MBIA).

165. In general, bonds intended to be issued to institutional investors are generally assigned a unique CUSIP number at issuance, which represents a nine-character alphanumeric code used to identify a specific securities issue. The numbers are assigned by CUSIP (Committee on Uniform Security Identification Procedures), which is part of the American Bankers Association. Fedwire Securities Service Glossary, available at http://www.frbservices.org/operations/fedwire/service_glossary.html.

166. Ackman Letter, supra note 162, at 5. Specifically, MBIA's 25 insured CDOs consisted of securities that exposed it to 420 inner-CDOs and 3131 mortgage-backed securities. Ambac's 28 CDOs consisted of 
Having accumulated this data, the Open Source Model then calculated loss estimates for each tranche of MBS underlying the portfolio of CDOs insured by Ambac and MBIA. In general, the model estimated the cumulative losses that would affect a particular tranche of an MBS by assuming loss estimates based on its vintage year, original rating, and type of underlying collateral. For example, Alt-A fixed mortgages issued in the first half of 2006 that had an original rating of AA were assumed to suffer an $81.2 \%$ loss of principal, while AA subprime mortgages from the same vintage year were assumed to suffer a $19.8 \%$ loss of principal. ${ }^{167}$ The model then used data regarding the par amount of the MBS held by a particular CDO to estimate the loss the CDO would experience on the investment. ${ }^{168}$ If a CDO consisted entirely of MBS, aggregate expected losses in the CDO were estimated by simply adding the loss estimates for each MBS within it.

Based on these aggregate loss estimates for a CDO, the model then estimated how these losses would flow through the CDO's capital structure to affect specific tranches. Here, the model used considerably more lower-tier data than in the case of analyzing expected losses on a basic MBS. In particular, loss estimates for each tranche of a CDO were calculated using the value of the CDO collateral and cash that was most recently reported by the CDO's trustee as well as the subordination that applied to each tranche. For instance, in the case of Summer Street 2005-1, Ltd.-a CDO consisting entirely of 146 MBS - the model estimated that aggregate losses from its MBS would total \$145 million using the analysis summarized in the preceding paragraph. It then deducted this amount from the $\$ 403$ million of cash and collateral held by the CDO according to its trustee report dated December 31, 2007 to arrive at an estimated amount of total assets available for distribution to the CDO noteholders. Because the CDO had issued six tranches of notes having an aggregate face value of $\$ 400$ million, the model showed that the $\mathrm{CDO}$ would therefore have insufficient assets to pay back all tranches, resulting in a loss of $100 \%$ for all tranches of notes other than the senior-most tranche.

Notably, to estimate the loss on the senior class of securities, the model had to accommodate potential overcollateralization provisions. These provisions protect a CDO's senior tranche against potential loss by requiring accelerated amortization of the tranche in the event the ratio of senior securities to CDO assets falls below certain thresholds. ${ }^{169}$ Once triggered, interest payments owed to junior securities are then used to pay down the senior securities until the required ratio is restored. The Open Source Model addressed this issue by including a (customizable) assumption that the liquidation of all CDOs would occur within two years, over which time all principal and interest owed to junior securities would be used to reduce the principal owed to the CDO's

securities that exposed it to 389 inner-CDOs and 4179 mortgage-backed securities.

167. These estimates for subprime and midprime mortgages were based on the performance of a sample set of 1267 subprime and midprime mortgage-backed securities. Ackman Letter, supra note 162, at 6 . Loss estimates for Alt-A mortgages, closed-end second lien mortgages, and HELOCs were based on the delinquency rate for each rating/vintage subgroup. Id. at 18. Losses for Alt-A mortgages exceeded those of similarly rated subprime mortgages due to the fact that loss estimates were originally projected to be lower on Alt-A securities, leading these securities to have considerably less subordination at origination than in the case of subprime mortgages. Id. at 16 .

168. For instance, if a CDO held $\$ 5,000,000$ of an Alt-A fixed mortgage issued in the first half of 2006 that had an original rating of $\mathrm{AA}$, the $\mathrm{CDO}$ would be assumed to experience a loss of $\$ 4,060,000$ on this investment.

169. See Douglas J. Lucas, Laurie S. GoOdman \& Frank J. FabozzI, Collateralized DebT OBLIGATIONS: STRUCTURES AND ANALYSIS 20-21 (2006) (describing overcollateralization ratios). 
senior-most securities. In the case of Summer Street 2005-1, Ltd., for instance, approximately $\$ 7$ million of diverted interest payments were assumed to pay down the senior class of securities before liquidation, reducing the total loss on this class of securities to 4.7\%. Having estimated losses for each tranche of the Summer Street 2005-1 $\mathrm{CDO}$, the model could then calculate the expected loss for any outer-CDO that had invested in one of these tranches. 170

In the end, the Open Source Model used these techniques to derive loss estimates for $4168 \mathrm{CDO}$ tranches issued by a total of $534 \mathrm{CDOs}$. Of these, the 58 outer-CDOs insured by Ambac and MBIA were estimated to produce losses for the insurers of more than $\$ 13$ billion. It was an amount that was considerably greater than the estimates that had been announced by the companies ${ }^{171}$ and, as the future would reveal, considerably closer to the losses that the insurers would actually suffer. ${ }^{172}$ At the same time, it provided a seemingly clear example of the potential for sophisticated investors to use both "uppertier" and "lower-tier" derivative disclosures to enhance market efficiency.

Yet while the Open Source Model clearly reveals the ability of investors to process derivative disclosures, it is also notable for omitting publicly available information that would have significantly enhanced its accuracy. Indeed, release of the Open Source Model precipitated scathing rebukes by both MBIA and Ambac in early February 2008 in which they both criticized its "major errors and omissions"173 and "flawed analysis and misperceptions." 174 Among other things, the insurers criticized the model's failure to "take account of the structures of CDOs and our contracts that provide us protections" and to "appropriately capture the triggers and cash diversion mechanisms that support the senior interests." 175 These structures and cash diversion mechanisms, of course, were all described in the CDOs' publicly available prospectuses, and by failing to incorporate their actual mechanics, the model was unquestionably less accurate than it could have been.

Consider, for instance, the loss estimate for Kleros VI, Ambac's largest CDO exposure discussed previously. ${ }^{176}$ This multi-sector CDO was originated in June 2007 to invest in a portfolio of residential MBS, CDOs, and other asset-backed securities. ${ }^{177}$ In

170. For example, if another CDO invested $\$ 20,000,000$ in the senior securities of Summer Street 2005-1, the CDO would be expected to lose $4.7 \%$ on its investment, or $\$ 940,000$.

171. The model's estimate of CDO losses for Ambac, for instance, was six times greater than the company's estimate. Ackman Letter, supra note 162, at 8.

172. In the case of Ambac, for instance, Ackman projected losses on Ambac's CDO portfolio of approximately $\$ 7$ billion compared to Ambac's estimate of $\$ 1.1$ billion. Ackman Letter, supra note 162 , at 8 . Ambac eventually reported a net realized loss of $\$ 4.4$ billion on its CDO portfolio in 2008, see AMBAC 2008 ANNUAL STATEMENT, supra note 92, at 12, and a net realized loss of \$1.8 billion in 2009, see Ambac 2009 10K Report, supra note 26, at 12.

173. MBIA Letter, supra note 111

174. Letter from Douglas Renfield-Miller, Executive Vice President, Ambac, to the Honorable Eric Dinallo, Superintendent of Insurance, State of New York (Feb. 12, 2008) (on file with author).

175. MBIA Letter, supra note 111.

176. See supra note 144 and accompanying text (chronicling the downgrade of Kleros Preferred Funding VI).

177. See Kleros VI Prospectus, supra note 144, at 157 ("Most of the Collateral Debt Securities are expected to consist of Residential A Mortgage Securities, Residential B/C Mortgage Securities and Home Equity Loan Securities (collectively, 'RMBS'), CMBS and CDO Obligations meeting the eligibility criteria described herein."). 
total, it sold \$3 billion of securities, including \$2.4 billion of Class A-1S notes that Ambac insured. ${ }^{178}$ A cursory look at the prospectus for Kleros VI located on the Irish Stock Exchange website reveals that the remaining $\$ 600$ million of securities were all subordinate in right of payment to the Class A-1S notes, thereby providing the Class A1S notes with $20 \%$ subordination. ${ }^{179}$ It also reveals that the Class A-1S notes were protected by overcollateralization provisions entitling them to accelerated amortization in the event the CDO failed the Class A-1S overcollateralization test. ${ }^{180}$ As noted above, the Open Source Model included a provision for such overcollateralization provisions, but it assumed that the senior securities for Kleros VI were protected by just $5 \%$ subordination. As a result, the model significantly underestimated the amount of interest diversions that were payable on the Class A-1S notes. Rather than $\$ 6$ million over two years, the trustee reports for Kleros VI reveal that the Class A-1S notes received principal payments from November 1, 2007 through August 11, 2008 of over $\$ 36$ million. ${ }^{181}$

At the same time, however, the model's use of these rough assumptions in lieu of more accurate parameters did not uniformly aid Pershing Square in its efforts to critique the monolines' financial positions. Again, in the case of Kleros VI, the Open Source Model assumed that all interest payments on the junior securities would be paid towards the Class A-1S notes in the event of an overcollateralization breach. The CDO's prospectus, however, stated that any diverted interest payments were to be used first to satisfy the CDO's obligations under two swap agreements it had entered into with Merrill Lynch and UBS Securities (a total return swap and a credit default swap) before any payments could be made on the Class A-1S notes. ${ }^{182}$ As a result, none of the interest that was diverted from the CDO's subordinated notes after August 2008 went towards any principal payments on the Class A-1S notes; rather, it was all absorbed by the prioritized swap payments. ${ }^{183}$

Neither the model nor Pershing Square's accompanying letter explain why Pershing Square failed to use a more detailed analysis of each CDO's subordination and overcollateralization protections. That it failed to do so, however, was hardly surprising. The prospectus for Kleros VI was nearly 400 pages long and, as noted above, the rough assumptions used in the model were sufficient to generate estimates of CDO losses that were closer to reality than those of Ambac and MBIA. ${ }^{184}$ Accordingly, the notion of digging through an additional 300 to 400 pages for each of the 534 CDOs would have no doubt been dismissed as a waste of time and resources to the extent it was even considered.

178. Id. at 1 .

179. Id.

180. Id. at $109-10$.

181. KLEROS PREFERRED FUNDING VI, LTD., MONTHLY REPORT 2 (Oct. 27, 2008) (on file with the author).

182. Id.

183. KLEROS PREFERRED FUNDING VI, WATERFALl REPORT FOR QUARTERLY DiSTRIBUTION DATE OF 11/10/2008, at 1 (on file with the author); KLEROS PREFERRED FUNDING VI, WATERFALL REPORT FOR QUARTERLY DISTRIBUTION DATE OF 2/9/2009, at 1 (on file with the author); KLEROS PREFERRED FUNDING VI, WATERFALL REPORT FOR QUARTERLY DISTRIBUTION DATE OF 5/11/2009, at 1 (on file with the author); KLEROS PREFERRED FUNDING VI, WATERFALl REPORT FOR QUARTERLY DISTRIBUTION DATE OF 10/26/2009, at 1 (on file with the author).

184. See supra note 172 and accompanying text (discussing the difference between Ambac's estimated and actual losses). 
Yet in this regard, the model's inaccuracies with respect to these overcollateralization and subordination provisions highlight an important dimension in which more complex credit derivatives can impair informational efficiency. In particular, it was not the analytical complexity of these provisions so much as the logistic complexity of undertaking the analysis (i.e., the time-related positioning and utilization of resources) that appears to have contributed to their omission from the model. Ackman was, after all, a hedge fund manager who had for six years been betting on his ability to understand the risks associated with the monolines' entry into the structured finance market. That the technicality of these common indenture provisions might impede his ability to assess a CDO is thus difficult to imagine. On the other hand, his need to economize on time in light of the quickly changing state of the financial markets in 2008 may have contributed to a desire to avoid the delay and effort associated with locating over 500 individual prospectuses and hand-coding each one in a way that could be input into the model.

Additionally, the logistic challenges associated with collecting and analyzing CDO prospectuses may have been heightened by the considerable amount of other, more salient data concerning the performance of the CDOs. In the end, it was the specific collateral composition of each $\mathrm{CDO}$ and Ackman's assumptions regarding the performance of various asset classes of MBS that determined the model's results. Given the time considerations noted above, the importance of these primary data inputs to both the model and to the performance of the outer-CDOs could justifiably cause Ackman to disregard other, more granular items of information.

Of course, whether logistic complexity actually contributed to Ackman's decision to omit more refined subordination and overcollateralization parameters must remain speculative. Nor does the Open Source Model indicate how Ackman subsequently processed the six downgrade announcements examined in Part III. In all likelihood, they would have done little to change Ackman's trading strategy given that by January 31, 2008, he had already taken a significant short position in both Ambac and MBIA. ${ }^{185}$ Nonetheless, by providing a theory for how even a highly sophisticated arbitrageur could disregard material information he almost certainly could understand, this analysis of the Open Source Model highlights how the logistic challenges associated with analyzing a CDO might impede even those sophisticated investors who do, in fact, undertake the task of analyzing a company's derivative disclosures.

\section{ASSESSING THE EFFECTIVENESS OF DERIVATIVES DisClOSURE}

Based on the foregoing results, what conclusions can be drawn about the ability of enhanced disclosure to facilitate greater investor analysis of a firm's portfolio of complex credit derivatives? In general, the findings presented here suggest that the potential benefits may be considerably more speculative than current public policy proposals have assumed. Notwithstanding Pershing Square's impressive attempt to assess Ambac's exposure to multi-sector CDOs, the overall equity and CDS markets appear to have been much less effective in monitoring the credit quality of its disclosed positions. Moreover, Pershing Square's Open Source Model illustrated the very real logistic complexities that

185. Ackman Letter, supra note 162 , at 5. 
can hamper even a sophisticated investor's understanding of a firm's derivative exposures. In combination, these results thus provide little support for the notion that better disclosure of a firm's exposure to complex credit derivatives, in itself, might have lessened the uncertainty that afflicted capital markets for much of 2008.

At the same time, however, the Pershing Square analysis provides some reason to hope that enhanced disclosure of a firm's derivative exposures can result in more accurate asset pricing, albeit one that is more gradual in nature. As noted above, despite the limits of the Open Source Model, it nonetheless produced relatively accurate loss estimates for Ambac and MBIA compared to those offered by the insurers themselves. Publication of the model also prompted considerable debate among investors and regulators concerning the capital adequacy of the insurers, ${ }^{186}$ which may have helped encourage them to cut dividends and raise additional capital in the spring of 2008. ${ }^{187}$

Moreover, there remain compelling policy reasons to encourage a greater understanding of firms' credit derivative exposures within the marketplace. As noted previously, uncertainty regarding firms' exposure to credit risk played a critical role in the seizing-up of credit markets in 2008 , and it was a primary contributor to the volatility that plagued both debt and equity markets following the collapse of Lehman Brothers. Enhancing investors' understanding of firms' credit risk exposure could, in the first instance, help alleviate the very real costs this uncertainty poses to both the real and financial economy. Further, an important component of prudential banking regulation has long been for market discipline to help supplement regulatory bank oversight as a means to ensure the stability of the financial sector. ${ }^{188}$ The now-infamous ineffectiveness of regulators in understanding the risks embedded in financial firms' derivatives portfolios-such as the Office of Thrift Supervision's efforts to monitor AIG Financial Products or the SEC's abandoned effort to monitor investment banks through the Consolidated Supervised Entities Program-only heightens the need for market participants to provide a supplemental form of risk oversight. ${ }^{189}$ But as the Open Source Model demonstrates, market participants can fulfill this role only if they first have access to information concerning a firm's derivative exposures. ${ }^{190}$

186. See, e.g., Michael Rudnick, MBIA and Activist Get Defensive, THE DaILY DEAL, Feb. 18, 2008 (summarizing Ackman's debate with MBIA executives before a House Financial Services subcommittee on the state of the bond industry); Yves Smith, MBIA: The (Rating) Agency is Not Amused, NAKED CAPITALISM, Feb. 1, 2008, http://www.nakedcapitalism.com/2008/02/mbia-rating-agency-is-not-amused.html (last visited Oct. 8, 2010) (analyzing Ackman's Open Source Model).

187. Michael Rudnick, MBIA Ready to Split Its Books, THE DAILY DEAL, Feb. 27, 2008 (discussing MBIA restructuring); Tapan Panchal, Ambac Not To Split, Is Focused on Fresh Capital, SNL INSURANCE DAILY, Mar. 5, 2008 (discussing Ambac restructuring).

188. See, e.g., BASEl COMM. ON BANKIng Supervision, EnHancing Bank Transparency: PubliC Disclosure AND SUPERVISORY INFORMATION THAT PROMOTE SAFETY AND SOUNDNESS IN BANKING SYSTEMS (Sept. 1998), http://www.bis.org/publ/bcbsc141.pdf (arguing that market discipline and public disclosure promote a more stable banking system); see also Group of Thirty, Enhancing Public Confidence in Financial Reporting (2003), http://www.group30.org/pubs/pub_1274.htm (same).

189. See Patricia A. McCoy et al., Systemic Risk Through Securitization: The Result of Deregulation and Regulatory Failure, 41 CONN. L. REV. 1327, 1357-61 (2009) (summarizing OTS and SEC regulatory failures).

190. In this regard, the policy rationale for enhanced, mandatory derivative disclosures tracks in many ways the rationale for mandating the disclosure of other forms of firm-specific information that is unlikely to be disclosed voluntarily on account of a firm's inability to capture the social benefits that disclosure creates. As Merritt Fox has postulated, in an entirely voluntary disclosure regime firms might disclose a suboptimal amount 
We are left, then, with strong grounds for considering enhanced disclosures of firms' derivative exposures, but with empirical evidence that is at best mixed with respect to their efficacy. Moreover, skepticism concerning the potential for enhanced disclosure seems especially appropriate where disclosure is aimed at promoting financial stability as in section 115(f) of the Dodd-Frank Act. For in such instances the measure of a successful disclosure regime should presumably reflect not only the extent to which disclosures are rapidly processed by sophisticated arbitrageurs but also by the broader marketplace. And in this regard, the absence of a significant market reaction to the downgrades examined in Part III.C raises perhaps the greatest challenge for any version of enhanced derivatives disclosure. As regulators consider revising public disclosure regimes, an important first step should accordingly be to understand why the market did not react to these six CDO downgrades in the same fashion as it reacted to the more mundane downgrades of PG\&E in 2001.

A useful place to begin in this regard is Gilson and Kraakman's analysis of how information affects security prices in capital markets, ${ }^{191}$ which has long-dominated academic analysis of the relation between a firm's public disclosures and the informational efficiency of capital markets. Published in 1984, the article reflects in many ways the ascendancy of the Efficient Capital Market Hypothesis and the considerable amount of research in finance that had demonstrated the rapid pace with which information was impounded into security prices. Despite this body of research, however, there existed no account of the method by which information actually affected stock prices, which became the motivating question for Gilson and Kraakman's classic study. 192

By examining the mechanisms through which traders processed public information, Gilson and Kraakman concluded that four types of trading operated to affect security

of proprietary information concerning their operations on account of the fact that the disclosing firms will be unable to capture the significant value these disclosures provide to competitors. Merritt B. Fox, Retaining Mandatory Securities Disclosure: Why Issuer Choice Is Not Investor Empowerment, 85 VA. L. REV. 1335, 1339 (1999). This is especially true where disclosing proprietary information would cause the disclosing firm to suffer a competitive disadvantage. Michael D. Guttentag, An Argument for Imposing Disclosure Requirements on Public Companies, 32 FLA. ST. U. L. REV. 123, 147 (2004). Each of these concems may be particularly acute in the context of firms' investments in credit derivatives where release of trading strategies could greatly benefit other firms at the same time that they might harm the disclosing firm (for example, by allowing competitors to take an adverse trading position against the disclosed position). Indeed, that these considerations might deter a firm from voluntarily disclosing its derivative positions was clearly illustrated in the refusal of AIG and the New York Federal Reserve to disclose details about AIG's portfolio of insured CDOs until a member of Congress released the information to the media after a heated Congressional investigation into the lack of transparency surrounding AIG's rescue. See AIG Discloses Details on Toxic Securities, ASSOCIATEd PrESS, Jan. 29, 2010 (detailing the Federal Reserve's fear that disclosure will make the resale of assets more difficult). To be sure, imposing a more expansive disclosure regime would also entail considerable costs to the disclosing firms, and a full examination of the normative case for enhanced disclosure requires a more nuanced costbenefit analysis. Cf. Roberta Romano, The Need for Competition in International Securities Regulation, 2 THEORETICAL INQUIRIES L. 387, 432-33 (2001); Guttentag, supra, at 163-69. The primary point here is simply to emphasize that, notwithstanding the inefficacy of the monolines' derivative disclosures in 2008 , there nevertheless remain a number of theoretical benefits of an enhanced disclosure regime. It is these benefits that justify an examination of how we might use the monoline experience to maximize the possibility of capturing them.

191. Gilson \& Kraakman, supra note 45.

192. Id. at 553 . 
prices, ${ }^{193}$ only one of which truly relied on the processing of a company's public disclosures. In particular, while traders might value firms based on generally known news such as a Federal Reserve interest rate increase ("universally informed trading" ${ }^{194}$ ) and others might value firms based on decoding a firm's stock price movements ("derivatively informed trading"195), it was "professionally informed trading" that relied primarily on the processing of a company's public disclosures. ${ }^{196}$ By searching for and processing a company's disclosures, professional traders used a combination of long and short strategies to move a company's price from its "uninformed" price levels, forcing prices to reflect the consequence of a particular disclosure. ${ }^{197}$ The speed with which this process occurred--and the informational efficiency of the market-therefore depended on the distribution of disclosed information among professional traders. This, in turn, depended on the costs investors faced in acquiring, processing, and verifying it. ${ }^{198}$

Writing 20 years later, Gilson and Kraakman again revisited the mechanisms of market efficiency following the advent of behavioral finance. ${ }^{199}$ During the 1980 s and 1990 s a large literature in finance had documented numerous instances in which significant mispricing could persist in capital markets on account of any number of cognitive limitations affecting individual investors, ${ }^{200}$ which seemed to challenge the efficiency with which markets processed information. Gilson and Kraakman acknowledged that these findings appeared to undermine their empirical claim that professionally informed trading caused prices to reflect rapidly public disclosures, but they were reluctant to concede that cognitively-biased trading undermined their overall framework. $^{201}$ As Andrei Shleifer and Lawrence Summers have noted, the mispricings identified by behavioral finance depend ultimately on two phenomena: the existence of

193. Id. at 566 (describing “'universally informed trading,' 'professionally informed trading,' 'derivatively informed trading,' and 'uniformed trading"').

194. Id. at $568-69$

195. Id. at 572-79.

196. Gilson \& Kraakman, supra note 45 , at 569-72. The fourth category of trading, uniformed trading, did not systematically rely on any particular type of information. Id. at 579-88.

197. See id. at 570 ("II]nformed traders ... can also cause prices to reflect information by persistent trading at a premium over 'uninformed' price levels.").

198. Id. at 593 ("The lower the cost of particular information, the wider will be [the information's] distribution, the more effective will be the capital market mechanism operating to reflect,it in prices, and the more efficient will be the market with respect to it.").

199. Gilson and Kraakman, supra note 142 , at 715 .

200. For an overview of what has become a vast literature in finance, see generally Barberis \& Thaler, supra note 157 . For an introduction to a similarly impressive amount of legal scholarship examining behavioral finance, see Donald C. Langevoort, Taming the Animal Spirits of the Stock Markets: A Behavioral Approach to Securities Regulation, 97 NW. U. L. REV. 135 (2002) (examining the debate over the validity of the efficient market hypothesis); Stephen Bainbridge, Mandatory Disclosure: A Behavioral Analysis, 68 U. CIN. L. REV. 1023 (2000) (critiquing the overwhelming endorsement of behavioral economics); Stephen J. Choi \& A.C. Pritchard, Behavioral Economics and the SEC, 56 STAN. L. REV. 1 (2003) (analyzing behavioral economics in the context of securities regulation enforcement); Lawrence A. Cunningham, Behavioral Finance and Investor Governance, 59 WASH. \& LEE L. REV. 767 (2002) (discussing the ascendancy of behavioral finance theory); Robert A. Prentice, The Case of the Irrational Auditor: A Behavioral Insight Into Securities Fraud Litigation, $95 \mathrm{Nw}$. U. L. REV. 133 (2000) (arguing that the behavioral approach to finance most accurately describes reality); Lynn Stout, The Mechanisms of Market Inefficiency: An Introduction to the New Finance, $28 \mathrm{~J}$. CORP. L. 635 (2003) (describing the prominence of behavioral finance scholarship).

201. Gilson \& Kraakman, supra note 142 , at $741-42$. 
biased investors and the existence of significant arbitrage costs. ${ }^{202}$ Given Gilson and Kraakman's hypothesis regarding how professional traders moved prices off their "uniformed" price through long and short trading strategies, their response to the behavioral challenge focused on how limits to arbitrage likely interfered with this mechanism. ${ }^{203}$ Specifically, they contended that professional traders might fail to use short-selling strategies owing to a combination of both institutional limits on short-sales (such as the uptick rule and a limited supply of shares) and more basic business risks associated with short-selling (such as the risk that noise traders will continue to be irrational), thereby maintaining a mispricing. ${ }^{204}$ While they acknowledged that "the existence of irrational professional traders may be a limit to arbitrage," they were reluctant to treat arbitrageurs as other than rational actors, noting that when "individuals [are placed] in a position where the goal is to make money, the cognitive biases seem to disappear quickly."205

By juxtaposing the role of arbitrage limits and behavioral bias in explaining why professional trading might not correct market mispricings, Gilson and Kraakman thus provide a useful means to examine the absence of significant market reactions to Ambac's CDO downgrades. Most notably, the evidence presented here would seem to suggest that, contrary to Gilson and Kraakman's hypothesis, the absence of a market reaction to the downgrades was unlikely the result of arbitrage limits alone. Indeed, as noted previously, one of their primary policy reforms for enhancing market efficiencythe abolition of the uptick rule 206_-had been implemented for all of 2008. Nor were Ambac and MBIA small capitalization companies trading on illiquid exchanges where arbitrage tends to be more difficult. ${ }^{207}$ On the contrary, during both the PG\&E bankruptcy and the Financial Crisis both MBIA and Ambac were closely-scrutinized companies with significant analyst coverage whose shares traded on the highly liquid New York Stock Exchange. ${ }^{208}$ Moreover, many of the business risks of short-selling emphasized by Gilson and Kraakman, such as the risk that noise traders will fail to see that a stock is over-valued, ${ }^{209}$ are more relevant in deterring short-selling in stock market bubbles-where asset values might remain over-valued for a significant period of timethan in a declining market such as occurred in 2008. Of course, other restrictions on short-selling persisted in $2008,{ }^{210}$ and short-selling continued to pose a number of risks. However, none of these ultimately appeared to have posed a significant deterrent to

202. See Andrei Shleifer \& Lawrence H. Summers, The Noise Trader Approach to Finance, 4 J. EcON. PERSPECTIVES 19, 19-20 (1990) (discussing the conditions under which markets may fail to be efficient).

203. Gilson \& Kraakman, supra note 142, at 733.

204. Id. at $726-27$.

205. Id. at $730-31$.

206. See id. at 738 (advocating repeal of uptick rule).

207. See id. at 735 (noting evidence that many pricing anomalies analyzed in behavioral finance disappear when the studies control for company size, for which there is more available information).

208. Based on the $\mathrm{I} / \mathrm{B} / \mathrm{E} / \mathrm{S}$ Analyst Historical Earnings Estimate Database, Ambac had between six and seven sell-side analysts that followed the firm in 2008; MBLA had between seven and eight.

209. See Gilson and Kraakman, supra note 142, at 726 (describing the risks noise traders pose to arbitrageurs).

210. Regulation $T$, for instance, imposes a cost on short-selling by requiring short-sellers to post margin worth $50 \%$ of the value of the borrowed securities. 12 C.F.R. $\$ 220.1, \mathrm{n} .16(2008)$. 
prospective short-sellers in 2008 given that, as noted in Part IV, short-selling was quite simply raging in Ambac for most of the year.

In light of these circumstances, there are good reasons to examine whether some form of behavioral bias might provide a convincing explanation for the absence of a marketplace reaction to the six downgrades examined in Part III. An appealing candidate in this regard is a recent line of research examining the role of investor distraction in analyzing and processing information in capital markets. ${ }^{211}$ Building on the considerable work in psychology examining how an individual's attention constitutes a scarce resource, ${ }^{212}$ finance scholars working in this area have sought to provide both theoretical and empirical accounts of how individuals' limited attention might systematically affect the market's response to publicly available information. Recent theoretical models, for instance, have examined how limited investor attention can lead to mispricings related to publicly available accounting information, ${ }^{213}$ a faster rate of incorporation of information for larger companies than for smaller companies, ${ }^{214}$ and neglect of longer-term information. ${ }^{215}$

Empirically too, scholars working in this field have sought to document the various ways in which investor inattention might affect significantly stock price reactions. Many of these studies involve the market's failure to respond to news until it was rebroadcast in a more salient fashion in much the same way that Ambac's CDO downgrades failed to produce a significant stock price reaction until Ambac itself announced their effect on its earnings. For instance, in their single-firm event study of the pharmaceutical company EntreMed, Gur Huberman and Romer Regev found that EntreMed's stock price soared following the release of positive news concerning its cancer-curing drugs in the New York Times, even though the more academic journal Nature had previously published the same information five months earlier with no stock market response. ${ }^{216} \mathrm{~A}$ similar delayed reaction to widely-dispersed but less salient news appears in Lauren Cohen and Andrea Frazzini's analysis of stock price reactions across customer-supplier links. ${ }^{217}$ By examining the SEC filings of a sample of publicly-traded firms, Cohen and Frazzini

211. See, e.g., David Hirschleifer et al., Driven to Distraction: Extraneous Events and Underreaction to Earnings News, 64 J. FiN. 2289, 2322 (2009) ("A mainstay of behavioral asset pricing theory is the idea that several important return anomalies represent market underreactions to information. A leading explanation for such underreaction is that investors with limited attention neglect newly arriving information signals.").

212. See generally DANIEL KAHNEMAN, ATTENTION AND EFFORT (1973) (modeling attentive mental processing as a problem of scarce resource allocation); HAROLD E. PASHLER, THE PSYCHOLOGY OF ATTENTION (1998) (reviewing research on attention); Lisa Feldman Barrett et al., Individual Differences in Working Memory Capacity and Dual-Process Theories of the Mind, 130 PsYCHOL. Bull. 553 (2004) (investigating individual differences in the ability to control attention).

213. See David Hirshleifer \& Siew Hong Teoh, Limited Attention, Information Disclosure, and Financial Reporting, 36 J. ACCT. \& ECON. 337, 339 (2003) (analyzing investors' attentiveness to market information).

214. See Lin Peng, Learning with Information Capacity Constraints, 40 J. Fin. \& QUANT. ANALYsIS 307, 321 (2005) (reporting studies on the speed of security price adjustment).

215. See Stefano DellaVigna \& Joshua M. Pollet, Demographics and Industry Returns, 97 AM. ECON. REV. 1667,1667 (2007) (presenting a model of inattention to information about the distant future to explain the empirical relation between forecastable demographic demand shifts and abnormal stock returns for specific industries).

216. Gur Huberman \& Tomer Regev, Contagious Speculation and a Cure for Cancer: A Nonevent that Made Stock Prices Soar, 56 J. FIN. 387, 387-88 (2001).

217. Lauren Cohen \& Andrea Frazzini, Economic Links and Predictable Returns, 63 J. FIN. 1977 (2008). 
identified all customers of their sample firms that accounted for more than ten percent of a firm's aggregate sales and then examined how negative news about such customers affected a supplier's stock price. ${ }^{218}$ Surprisingly, Cohen and Frazzini found that the release of adverse news concerning a major customer's business projections did not result in any meaningful change in a supplier's stock price until the subsequent announcement by the supplier of its (predictable) sales decline. ${ }^{219}$ Cohen and Frazzini conclude that these delayed reactions to customers' adverse news may be due to investors' limited attention. 220

By highlighting how investor inattention might impair the processing of important but low salient information, these studies provide a potentially useful means to understand the way in which Ambac's investors may have been processing information in the spring of 2008. Despite the economic consequence of the CDO downgrades examined in Part III.C, the downgrade of "Kleros Preferred Funding VI" or "Cairn High Grade ABS CDO II" undoubtedly had less salience for most investors in Ambac compared to when Ambac simply announced the adverse effect of the downgrades on its earnings. Moreover, the significant amount of extraneous news occurring in 2008 following the collapse of the housing sector may have further compromised the ability of investors to focus on the consequence of CDO downgrade announcements. ${ }^{221}$ Indeed, one of the most notable differences between the monolines' experiences during PG\&E's credit turmoil compared to the Financial Crisis was the seemingly low attention paid within the media to the monolines' individual CDO exposures compared to their PG\&E exposures. As noted previously, the California energy crisis produced prompt, widespread speculation within the financial press regarding the consequence of a PG\&E bankruptcy on both Ambac and MBIA. In contrast, a Factiva search covering 2005 to 2009 reveals not a single media or news release that mentions in the same story or report the word "Ambac" or "MBIA" and the specific name of any of their insured CDOs.

The final liquidation of Kleros VI provides a dramatic illustration of the disparity between Ambac's closely-followed exposure to PG\&E's bonds and the oblivion of its individual CDO positions. Having issued \$3 billion of CDO notes in 2007 (of which $\$ 2.4$ billion were insured by Ambac), Kleros VI announced to its investors on August 3, 2009 that it would liquidate, ${ }^{222}$ eventually disposing of its collateral securities by means of public auction on September 22 and September 23. ${ }^{223}$ The auctions, however, yielded just pennies on the dollar for the majority of its securities, ${ }^{224}$ meaning that (as predicted by the Open Source Model) Ambac would most likely experience a significant loss payout on this extraordinarily large policy. Not surprisingly, on October 2, 2009, Kleros VI issued a notice on the Irish Stock Exchange stating that its final assets would be

218. Id. at 1983-84.

219. Id. at $1979-80$.

220. Id.

221. Cf. Hirschleifer et al., supra note 211 , at 2289 (finding that "the immediate price and volume reaction to a firm's earnings [announcement] is much weaker, and the post-announcement drift of the stock price much stronger, when a greater number of same-day earnings announcements are made by other firms").

222. Kleros Preferred Funding VI, Ltd., Notice of Acceleration and liquidation, (Aug. 3, 2009), available at http://www.ise.ie/app/announcementDetails.asp? $\mathrm{ID}=10134416$.

223. Wells Fargo Bank, Revised Notice of PUblic Sale and InVITATION to Bid, (Sept. 11, 2009), available at $\mathrm{http}: / / \mathrm{www} . i \mathrm{se}$.ie/app/announcementDetails.asp?ID=10189220.

224. KLEROS PREFERRED FUNDING VI, LTD., MONTHLY REPORT, (Oct. 26, 2009), at 13-18. 
insufficient to pay the principal on the Class A-1S notes, ${ }^{225}$ and on October 16,2009 it announced it had distributed all remaining assets to the holders of the Class A-1S notes. $^{226}$ The final trustee report dated October 27, 2009 indicated that the Class A-1S notes were paid over the life of the transaction just $17 \%$ of their $\$ 2.4$ billion of principal, creating a principal deficiency on the insured notes of nearly $\$ 2$ billion. ${ }^{227}$ Notwithstanding the potential implications of this announcement for Ambac, not a single news outlet during the months of September or October 2009 mentioned either Ambac's potential exposure to the Kleros VI liquidation or, for that matter, the liquidation itself. ${ }^{228}$

Ultimately, whether or not investor inattention accounted for the absence of a significant market reaction to Ambac's CDO downgrades must remain tentative given the limited data available concerning the motivations of Ambac's investors. Indeed, the one Ambac investor for which there exists public information detailing its analysis-Bill Ackman's Pershing Square Capital-was notable for its seemingly unique focus on the credit quality of Ambac's individual CDO positions. Yet even here, Ackman's longstanding campaign against the monoline industry seems to illustrate the need to take seriously the challenge that investor inattention poses to effective derivative disclosure. After all, a notable theme in Ackman's five-year dispute with the monolines was his desire to publicize and market his analysis of their derivatives portfolios, often at the risk of incurring potential market manipulation liability. ${ }^{229}$ In the process, Ackman's actions suggest a deep concern with a challenge facing all arbitrageurs, but which may be especially important with respect to derivatives analysis-namely, that uninformed investors will remain uninformed of the underlying risks, thereby inhibiting arbitrageurs from profiting from their investment in research. ${ }^{230}$ In short, by broadcasting the Open Source Model in the pages of the New York Times, Ackman's marketing effort reflects a bold attempt to grab the attention of a marketplace that might be too distracted to focus on Ambac's obscure-sounding CDO exposures.

These tentative conclusions regarding the absence of a market reaction to Ambac's CDO downgrades, combined with the case study of Perhsing Square's Open Source model, suggest at least two considerations for investors and regulators to consider as they grapple with the optimal form of derivatives disclosure. First, despite the oft-noted complexity of credit derivatives, Pershing Square's Open Source model suggests that the logistic complexity of analyzing CDOs-rather than their analytic complexity-may

225. Wells fargo Bank, Notice of Status of Liquidation and Distribution, (Oct. 2, 2009), available at http://www.ise.ie/app/announcementDetails.asp?ID=10224134.

226. Wells FARGO BANK, NOTICE OF DisTRIBUTION, (Oct. 16, 2009), available at http://www.ise.ie/app/ announcementDetails.asp? $\mathrm{ID}=10235757$.

227. Kleros Preferred Funding VI, Ltd., Interest and Principal Waterfall Report, (Oct. 26, 2009).

228. In an 8-K filed on November 18, 2009, Ambac announced the commutation of four unnamed CDOs having an aggregate notional balance of $\$ 5,031$ million. See Ambac, Current Report (Form 8-K) (Nov. 18, 2009), http://www.sec.gov/Archives/edgar/data/874501/000119312509237201/d8k.htm. Review of this $8 \cdot \mathrm{K}$ alongside Ambac's quarterly operating supplement released that same day (which, for the first time, omitted Kleros VI) suggests that Kleros VI was among the four commuted CDOs.

229. See supra note 160 (discussing Eliot Spitzer's investigation of Ackman for potential market manipulation following Ackman's release of negative reports about MBLA) .

230. This well-known risk faced by arbitrageurs is nicely illustrated by the Wall Street aphorism, "a bargain that stays a bargain is no bargain." See Stout, supra note 200, at 655 (quoting The Wall Street Journal). 
often play a primary role in distracting even highly-motivated, sophisticated investors from a full and accurate understanding of a CDO portfolio. The findings of this Article therefore serve to emphasize the need for disclosure regimes to consider the very real logistic challenges facing investors analyzing complex derivatives such as securitizations and, where possible, to economize the computational effort required to assess them. In this regard, the SEC's 2008 mandate for all Exchange Act reporting companies to provide financial statements to the SEC in an interactive data format using eXtensible Business Reporting Language (XBRL) is a promising first step in this direction. ${ }^{231}$ By requiring financial statement data to be filed with the SEC in a digitized format, XBRL has the potential to increase the speed and usability of financial disclosures by minimizing the transcription costs and logistic challenges associated with real-time evaluation of firms' periodic filings. While the XBRL requirement currently applies only to financial statement data, the system would appear particularly useful in analyzing a firm's exposure to complex credit derivatives (such as CDOs) that, as illustrated by the Open Source model, require the rapid processing of hundreds and even thousands of interconnected underlying securities.

Second, the potential role of more widespread inattention to a firm's non-salient investment activities also highlights the need to consider the ways in which even disclosed information might have to compete for investors' attention. Notwithstanding the growing body of finance research highlighting the prevalence of investor inattention, ${ }^{232}$ remarkably little research exists examining the precise relation between investor inattention and the form of investor disclosures. ${ }^{233}$ Yet as the Huberman and Regev study reveals, the salience of a disclosure can significantly affect the speed of the market's incorporation of information, suggesting the potential for the form of disclosure to help mitigate the challenge of investor inattention. ${ }^{234}$ In this regard, disclosure regulations might also benefit from recent work in experimental social psychology that also examines how changing the manner in which form contracts are presented to consumers can enhance both readership and comprehension. ${ }^{235}$ Experimental research on

231. In December 2008, the SEC voted to require specified companies and mutual funds to provide financial statements, notes and schedules to the SEC in XBRL. Large accelerated filers who file using U.S. GAAP and who have a public float above $\$ 5$ billion were required to make XBRL filings for their first quarterly reports for fiscal periods ending on or after June 15, 2009. All other large accelerated filers who file using U.S. GAAP will be required to make XBRL filings for their first quarterly reports for fiscal periods ending on or after June 15, 2010, and all remaining companies who file using U.S. GAAP (including smaller reporting companies) will be required to make XBRL filings for their first quarterly reports for fiscal periods ending on or after June 15, 2011. Companies reporting in Intemational Reporting Financial Standards will also be required to submit XBRL filings starting with fiscal years ending on or after June 15, 2011. See Interactive Data to Improve Financial Reporting, Exchange Act Release No. 33-9002, 34-59324, 39-2461, 17 C.F.R. Parts 229, 230, 232, 239, 240, and 249 (Jan. 30, 2009) ("adopting rules requiring companies to provide financial statement information in a form that is intended to improve its usefulness to investors").

232. See supra notes 211-28 and accompanying text (examining behavioral bias as a possible reason for marketplace inaction following Ambac's downgrades).

233. For a notable exception, see Donald C. Langevoort, Toward More Effective Risk Disclosure for Technology-Enhanced Investing, 75 WASH. U. L.Q. 753, 759 (1997) (exploring the implications of behavioral finance on the proper form of risk disclosures ).

234. See supra note 216 and accompanying text (discussing the results of the Huberman and Regev study of EntreMed).

235. See Robert P. Bartlett, III \& Victoria C. Plaut, Blind Consent? A Social Psychological Investigation of 
the relationship between investor disclosures and inattention could similarly provide an initial step in understanding how the form of disclosure might enhance the salience of both voluntary and mandatory derivative disclosures.

\section{CONCLUSION}

As regulators consider imposing additional disclosures on systemically important financial institutions, ${ }^{236}$ the experience of the monoline industry during the Financial Crisis provides a unique window into the potential for enhanced derivatives disclosure to resolve the informational uncertainty that plagued financial markets in 2008. Like AIG Financial Products, monoline insurers stood at the center of the Financial Crisis in light of their key role insuring the super-senior tranches of multi-sector CDOs tied to residential mortgages. In contrast to AIG, however, a remarkable coincidence of statutory accounting rules, European securities reform efforts, and CDO underwriting practices made their significant portfolios of multi-sector CDOs very much open to public scrutiny during the lead up to the Financial Crisis.

Despite the possibility for independent analysis of their portfolios, however, the overall results from this study indicate that investors in monoline insurers showed little evidence of efficiently processing monoline derivative disclosures during the Financial Crisis. The experience of the monoline industry in 2008 therefore stands in notable contrast with its experience seven years earlier when investors and news outlets alike closely tracked the monolines' exposure to the California energy crisis. While the considerable differences between the two experiences make comparisons challenging, this Article has suggested that the low level of salience associated with CDOs may account for the striking difference.

To the extent this is the case, the results of this study indicate that the traditional disclosure model aimed at simply disseminating information to the public domain is unlikely to have significant efficacy when it comes to disclosures pertaining to complex credit derivatives. Indeed, the patchwork of derivative disclosures that applied to monolines' CDO exposures in 2008 was in many ways a real-life illustration of just such a regime, albeit if accidental in creation. That it appeared to yield only modest, if any, results in terms of resolving the uncertainty associated with credit derivatives suggests a need to move beyond this traditional approach and to consider the complex pattern in which the form of disclosure can matter even for sophisticated investors.

the Non-Readership of Click-Through Agreements (UC Berkeley School of Law Working Paper, 2009), available at $\mathrm{http} / /$ www.escholarship.org/uc/item/3wq2q5dx?display=all (presenting evidence of inattentiveness to click-through agreements).

236. See supra note 4 and accompanying text (summarizing proposals for increased transparency of firms' exposure to derivatives). 
*** 